\title{
Molecular Genetic of Human Male Infertility: From Genes to New Therapeutic Perspectives
}

\author{
Peter H. Vogt*
}

FINAL.

\author{
Section Molecular Genetics \& Infertility, Dept. Gynecol. Endocrinol. \& Reproductive Medicine, University of \\ Heidelberg, D-69115 Heidelberg, Germany
}

\begin{abstract}
Genetic lesions causing human male infertility are manifold. Besides gross chromosomal aneuploidies and rearrangements, microdeletions and single gene defects can interfere with male fertility. Male fertility is not only dependent on genes controlling the male germ line but also on genes of the networks functional for male gonad development and male somatic development, respectively. It is popular to unravel these netweorks with mouse gene knock-out mutants displaying reproductive defects. However, substantial arguments can be given for more functional studies directly on the human genes, because multiple reproductive proteins evolve quickly most likely for adopting to the specific needs of the species class. Prominent examples are mutations of the FSHR gene causing different pathologies in mouse and human and the DAZ gene family not found in the mouse genome but in the human genome with an essential male fertility function. Therefore this review is focussed on a comprehensive overview of human genes known with mutations causing male infertility (AR; AZF gene families; CFTR, DM-1, DNAH gene family, FGFR1, FSHR, INSL3, KAL-1, LGR8- GREAT, LHR, POLG). Then some human genes are described well recognised as functional in spermatogenesis and male fertility although gene specific mutations causing infertility were not yet identified (CREM, CDY1, DAZL1, PHGPx, PRM-1, PRM-2). They are designated as "spermatogenesis phase marker" or "male fertility index" genes, because they are useful tools for diagnosing the patient's' spermatogenesis disruption phase and for predicting the presence and quality of his mature sperms. Current therapeutic protocols for human male infertility do usually not cure the specific gene defect but try to bypass it using Artificial Reproductive Technology (ART). Putative imprinting defects in the early embryo probably associated with the used ART protocol and an increase of chromosome abnormalities in the ART offspring now strongly asks for a significant improvement of this outcome requesting urgently more basic research on the genes functioning in the human male germ line and during early human embryogenesis.
\end{abstract}

Key Words: AZF locus; Androgen-receptor; Chromosome aneuploidies; CF-CBAVD locus; Cryptorchidism; IdiopathicHypergonadotropic-Hypogonadism, Genetic load factor; Imprinting; Kartagener; Klinefelter.

\section{INTRODUCTION}

Human male infertility is a major health problem worldwide. Its prevalence in Western countries has been estimated with $20 \%$ [1]. Anatomic defects, endocrinopathies, immunologic problems, ejaculatory failures and environmental exposures are significant causes of infertility. Frequently, however, no clear cause for the observed infertility could be diagnosed coining the term "idiopathic infertility". At least in part, this is the result of our still poor understanding of the basic mechanisms regulating the genetic networks controlling male fertility, respectively, the molecular genetic of male infertility. It is assumed that in about $30 \%$ of cases male infertility is caused by chromosome aberrations or mutations in genes functioning in the male germ line. From mouse and Drosophila knock out experiments it has been deduced that the products of more than 3000 genes are involved in the genetic control circuits regulating the expression of male (and female) fertility [2-4]. Thereby it become obvious that male fertility is not only dependent on the genetic network of the germ line but include the networks functional for male gonad

\footnotetext{
*Address correspondence to this author at the Voßstrasse 9, D-69115 Heidelberg, Germany; Tel: +49-6221-567918; Fax: +49-6221-5633710; E-Mail: peter_vogt@med.uni-heidelberg.de
}

development, and male somatic development. The presence of genetic switch signals have been proposed for linking these networks and/or for controlling them [5, 6].

In human, the molecular identification of male fertility genes is hampered by the fact that human is not an experimental species. An infertile man is only recognised after the couple desiring for a child has asked for some therapeutic treatments in an infertility clinic [7]. Unfortunately, however, clinical examination of these couples only extends then to an analysis of their genetic conditions if the diagnose is "idiopathic infertility". A general overview of genetic defects causing male infertility is therefore restricted to only a subgroup of infertile man, although this subgroup is large with about $40 \%$. However, it is unknown whether a general genetic analysis of all infertile men would not also influence the therapeutic protocol of some other patient groups.

Genetic lesions causing male infertility can be roughly grouped in three classes: (1) Chromosomal aneuploidies and rearrangements where batteries of genes on specific chromosomes have increased their expression dosage or changed their normal genomic environment; (2) submicroscopic deletions (i.e. microdeletions) where deletions or rearrangements of multiple genes mapped in a molecular neighbourhood have changed their normal 
expression pattern and (3) single gene defects where the expression of a single gene (also called key element) is changed or lost causing then male infertility.

\section{CHROMOSOME ABERRATIONS WHICH CAUSE MALE INFERTILITY}

Aneuploidies or structural aberrations are found in about $14 \%$ of azoospermic men (i.e., infertile patients with no spermatozoa in their semen fluid) and $5 \%$ of oligozoospermic men (i.e., infertile patients with a severe reduction in the number of spermatozoa in their semen fluid) [8]. Most chromosome abnormalities causing male infertility include one of the sex chromosomes, $\mathrm{X}$ and Y, whereby the karyotype 47,XXY associated with the Klinefelter syndrome is the largest homogenous group. Although Klinefelter patients are usually azoospermic, individuals with a low number of spermatozoa in their testicular tissue can be found frequently [9] and reports of Klinefelter's who naturally fathered a child have been described in rare cases [10]. It is not yet known why Klinefelter patients are infertile, and why in about $20 \%$ of cases a mosaic karyotype, 46,XY/47,XXY is observed. But it has been speculated that the reduction of postmeiotic germ cells, generally observed in this patient group, is probably due to an interference of the pre-meiotic sex chromosomes' pairing process where the second $\mathrm{X}$ chromosome would compete with the $\mathrm{Y}$ chromosome. Mouse animal models, however, suggest an interference in the male germ line already during fetal life [11].

Klinefelter patients with increasing numbers of $X$ chromosomes in their karyotype (48,XXXY; 49,XXXXY) shift their sexual phenotype to the female site. Penis development is reduced and cryptorchidism is found in most cases. This suggests an X chromosomal dosage effect on the males' gonad development and that the balance of the sex chromosomes ( $\mathrm{X}$ and $\mathrm{Y}$ ) is crucial for this early embryonic process. Molecular isolation of a number of genes located and functional on both sex chromosomes ( $\mathrm{X}$ and $\mathrm{Y}$ ) have now provided first molecular support for this genetic balancer model "Fig. (1)". Since the X homologues are not inactivated by the general $\mathrm{X}$ chromosomal imprinting process, their increased expression in men with a 47,XXY karyotpye is expected. A major testicular germ cell tumour (TGCT) susceptibility gene linked with an history of undescended testis, UDT gene, has recently been mapped to $\mathrm{Xq} 27$ [12]. This would point to an increased risk for Klinefelter patients to develop a testicular tumour if they had an history of undescended testis in their childhood.

Men with a double $\mathrm{Y}$ chromosome in their karyotype $(47, \mathrm{XYY})$ also occur frequently $(1: 750)$ but their fertility status is variable. If infertile, they are usual oligozoospermic. Highly increased rates of YY bivalents observed during pachytene in the spermatocyte nucleus; 45-75\% [13] suggests that also in this patient group the normal formation of the X-Y paring complex in their germ cells is inhibited and therefore a major source of their infertility.

The mosaic karyotype $45, \mathrm{X} / 46, \mathrm{XY}$ leads to male infertility because of mixed gonad dysgenesis. It is found in infertile men with an incidence of $4 \%$. They are recognized in the clinic by a streak gonad at one site and a dysgenic gonad at the other site. Outer genitalia might be normal or presented with micropenis, hypospadia and small testis volumes. The occurrence of also female phenotypes with the same karyotype points again to the delicate balance of developmental decision(s) towards the male or female sexual pathway in early embryogenesis. Although the Y chromosome had a normal size in this patient group, it lacks the fluorescent staining block after banding with quinacrin, usually marking the Yq12 domain in the distal part of the Y long arm. These "non-fluorescent" Y chromosomes (Ynf) were then found to have a breakage in Yq11 with subsequent fusion of a second $\mathrm{Y}$ chromosome also broken in Yq11 forming a dicentric iso-Yp chromosome "Fig. (2)". Meiotic pairing of the $\mathrm{Y}$ to the $\mathrm{X}$ chromosome is inhibited because of self pairing of the iso-Yp between its doubled short arms [14]. This patient group therefore belongs to those with deletions of the Azoospermia Factor (AZF) in Yq11 (see below).

Men with azoospermia and the karyotype 45,X are also belonging to the AZF patient group "Fig. (2)". They have an unbalanced karyotype because the distal part of the euchromatic long Y arm (Yq11) is lost [15]. The other part of the Y chromosome including the SRY Gen locus is translocated to an autosome (most frequently to the short arm of one of the acrocentric chromosomes 13, 15, or 22).

The impact of balanced Y-A translocations on male fertility is variable because the same karyotypes were observed in fertile and sterile men sometimes even in the same pedigree [16]. In most familial cases, the distal heterochromatic part of the $\mathrm{Y}$ long arm (Yq12) is translocated to the short arm of an acrocentic chromosome and the $\mathrm{Y}$ chromosome is broken in Yq11 [17]. This patient class therefore belongs also to the AZF patient group "Fig. (2)". In two cases where an analysis of meiotic chromosomes was performed, it could be shown that the premeiotic $\mathrm{X}$ and $\mathrm{Y}$ pairing process is partly inhibited [18, 19]. Since the dynamic behaviour of this pairing process is known to be essential for the postmeiotic germ cell development [20], it can be stated that the general intactness of the chromatin structure in Yq11 is part of a chromosomally based $\mathrm{Y}$ fertility factor linked to the AZF locus (see also below the chapter of AZF chromatin folding code).

Azoospermic men with a 46,XX karyotype are found less frequently (1:20000 newborns). Male sex and gonad development is normal because the distal part of the short arm of the Y chromosome (Yp11), including the sexdeterming region $\mathrm{Y}$ (SRY) locus, is translocated to the distal part of the short $X$ chromosome arm (Xp22). Intersexual phenotypes (i.e. cryptorchidism, micropenis and hypospadia) are only observed when the X-Y-breakpoint-fusion-point is located in the neighbourhood of the SRY gene disturbing a timely activation of the SRY gene for male sex determination [21].

Chromosomal aneuploidies and translocations between autosomes (Robertsonian and reciprocal) were found less frequent than sex chromosomal abnormalities although structural aberrations (translocations, inversions) are found 10 times more frequently in infertile men than in the fertile men population. Especially, pericentric inversions in chromosome $1,3,5,6,10$ seem to interfere with meiosis leading to a reduced rate of postmeiotic sperm numbers or 


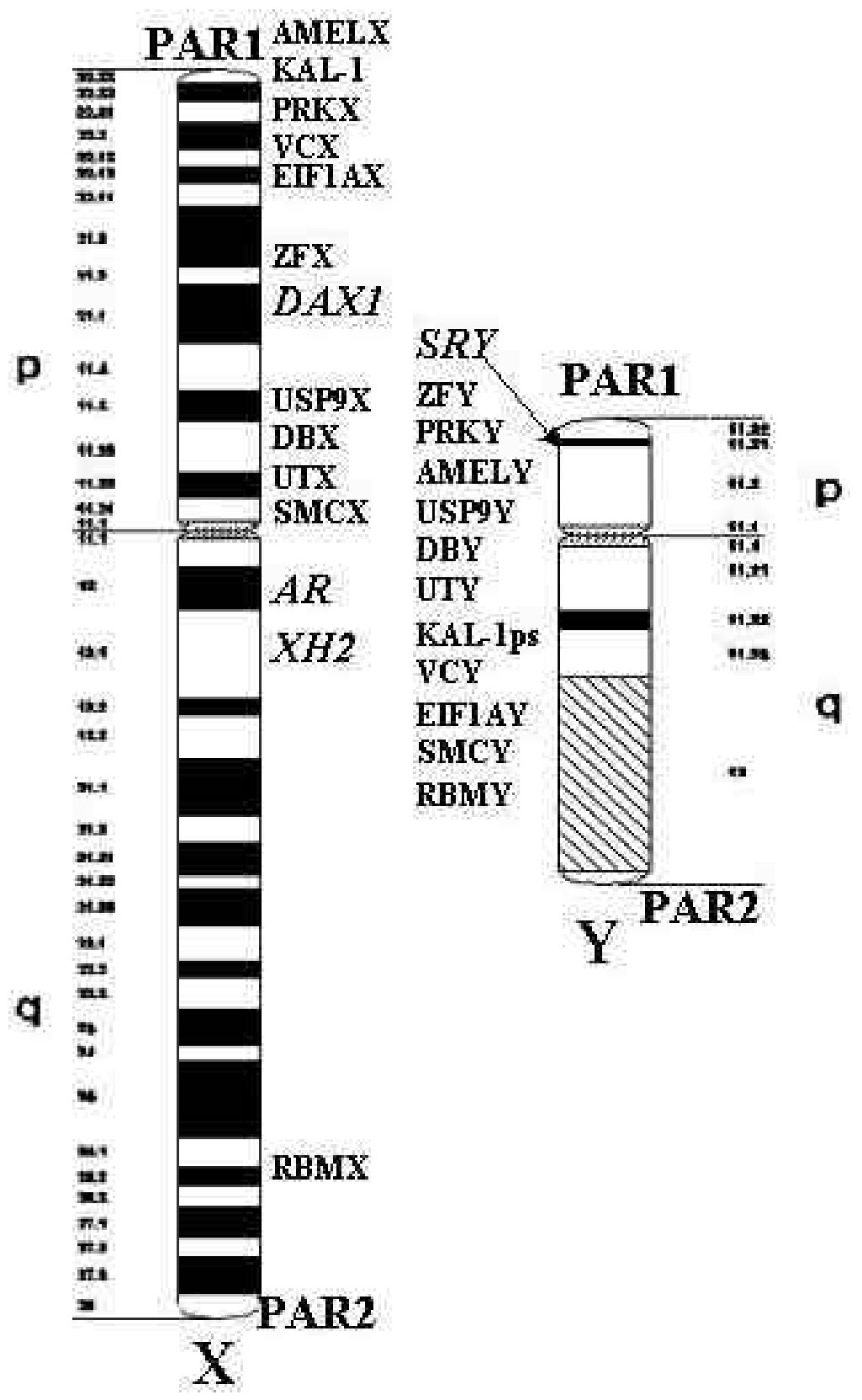

Fig. (1). Schematic view on current map of functional X-Y homologous genes. The Y-specific SRY gene is male sex determining, the Xspecific $D A X 1$ and $X H 2$ genes are testes and female sex determining, whereas the $\mathrm{X}$-specific androgen receptor $(A R)$ is a gonad-specific transcription factor functioning for male gonad development after binding androgens testosterone (T) and dihydrotestosterone (DHT), respectively. For further description of some single genes see text.

even azoospermia. In $60 \%$ of cases with Robertsonian translocations the two acrocentric chromosomes, 13 and 14, were involved [22]. Autosome aneuploidies like trisomies of chromosome 21 (Down syndrome), have individual effects on male fertility [23].

\section{THERAPEUTIC PERSPECTIVES FOR CHROMO- SOME ABNORMALITIES}

Chromosomally based male infertility factors are most likely associated with variabilities of the meiotic cell division process. This can be visualised by the variable occurrence of asynaptic chromosome regions in the synaptonemic complex [24, 25]. It can be assumed that all chromosome abnormalities are generally counter-selected by the meiotic segregation mechanisms [26]. The chromosome abnormalities found in the patient's lymphocytes need therefore not to be present in his postmeiotic germ cells. Therapeutic protocols for the treatment of chromosomally based male infertility must therefore include the confirmation of the patient's lymphocyte chromosome aberration in his mature germ cells. 


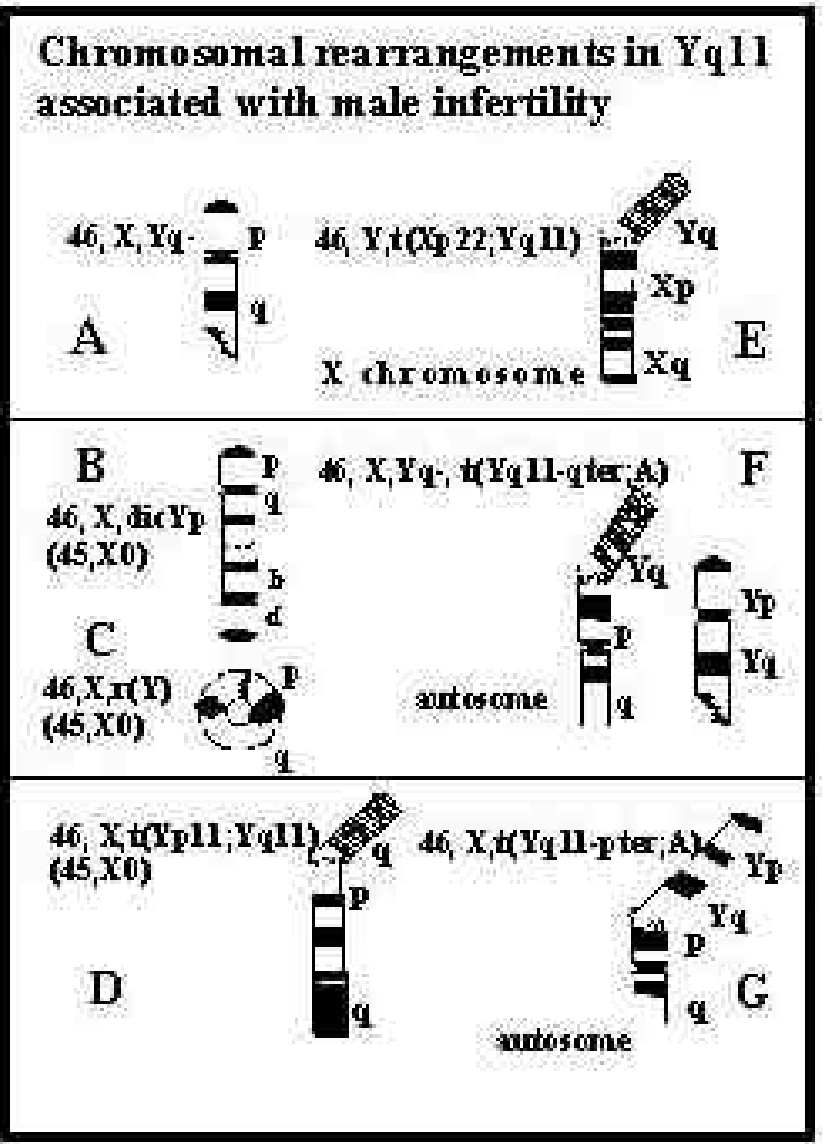

Fig. (2). Seven typical chromosomal rearrangements in Yq11 which are associated with the occurrence of infertility, azoospermia or oligozoospermia because of disruption of the $\mathrm{Y}$ chromosomal AZoospermia Factor (AZF) [14]. Monocentric Y chromosome with breakpoint in long $\mathrm{Y}$ arm (A) Dicentric iso-Yp chromosomes (B) and ring-Y chromosomes (C) are often found together with a 45,X0 cell line in the patient's lymphocyte nuclei pointing to the instability of the $\mathrm{Y}$ chromosome after these breakage events. Translocations of the $\mathrm{Y}$ chromosome broken in $\mathrm{Yq}$ are possible to the $\mathrm{X}$ chromosome $(\mathbf{E})$ and to autosomes $(\mathbf{F}, \mathbf{G})$ (mainly the acrocentric chromosomes 14, 15, 21).

However, a high incidence of sex chromosomal aneuploidies has been observed repeatedly in sperm samples also when the patient's sperm sample had a low morphological quality and the karyotype in lymphocytes was normal [2734]. This is because paternal nondisjunction of the meiotic chromosomes includes much more the sex chromosomes (X and $\mathrm{Y}$ ) than the autosomes, whereas aneuploidies of chromosome 13, 16, 18, 21 occur more frequently by maternal errors during the first and second meiotic division of the maturing oocyte [35]. A normal chromosome complement in the patients' lymphocytes can therefore not exclude an increased rate of aneuploidies in the postmeiotic germ cell.

By means of Fluorescence-In-Situ-Hybridisation (FISH) protocols it is now possible to analyse chromosome abnormalities in sperms directly [36]. A comprehensive analysis of the complexity of chromosome aberrations in infertile men would need a FISH protocol which paints each chromosome with a specific colour code [37]. However, in most cases DNA probes which mark distinct chromosome regions are preferred because the sperm chromatin is highly condensed and not-overlapping FISH spots for the analysis of single chromosome aneuploidies are requested. Sex chromosomes and chromosomes 1, 4, 6, 7, 8, 9, 10, 11, 12, 14, 16, 17, 18, 22 were analysed usually with FISH probes cloned from the chromosome specific alphoid repetitive sequence blocks in the centromeric regions of these chromosomes [38]. Chromosomes 13 and 21 are analysed with FISH probes generated from Bacterial-ArtificialChromosomes (BACs) cloned from specific chromosome regions (13q22 contig; 21q22.1 contig) [29]. FISH-labeling and detection kits including fluorochromes painting each chromosome with a specific colour code are now commercially available from different companies (e.g. Vysis; Oncor, Amersham).

An extensive FISH analysis on sperms of nine patients with severe oligoasthenoteratospermia (OAT syndrome) was performed by Pang et al. [29] using FISH probes specific for 14 chromosomes $(4,6,7,8,9,10,11,12,13,17,18,21$, X, $\mathrm{Y})$. They found a high increase of chromosomal disomies (frequency range: $0-5,4 \%$ ) compared with fertile control samples (frequency range: $0.05-0.2 \%$ ). Also the frequency of diploid chromosomes in the sperms of their OAT patients was significantly increased $(0.4-9.6 \%$; controls showed a mean of $0.04 \%$ ) and the total number of aneuploidies in sperms of the OAT patients was estimated with $33-74 \%$. The mean total aneuploidy in spermatozoa of fertile controls ranged between $4.1-7.7 \%$. All FISH germ cell studies report a significant increase of the aneuploidy rate of the sex chromosomes especially in men with OAT syndrome [33, 34]. This is most important for the therapeutic treatment of this patient group if one wants to apply artificial fertilisation technology (ART) with single sperms like ICSI (IntraCytoplasmic-Sperm Injection), which is not dependent on sperm morphology. Sex chromosome aneuploidies have a high risk to be transmitted to the offspring [39].

A major therapeutical draw back of the FISH analysis of sperms is the fact that sperms treated with the FISH protocol and identified then with a normal set of chromosomes can not be selected subsequently for the IVF/ICSI therapy. Since it seems also not safe to identify sperms with chromosome aneuploidies by a specific morphology or decreased motility [40], the risk factors for transfer of a specific chromosome anomaly to the IVF/ICSI offspring can only be based on a statistical evaluation of the patients' sperm samples. Obviously, this is not satisfying and only reasonable for patients with large sperm numbers, but not for patients with severe oligozoospermia (<1 million sperms) or even azoospermia.

It has now been reported that sophisticated testicular tissue expiration protocols (TESE) are able to extract single sperms from testicular biopsies of azoospermic Klinefelter patients in more than $40 \%$ of cases [41]. Using subsequently ICSI for fertilisation of the partner's oocytes, Klinefelter patients can now father a child. However, as expected these sperms have very often (but not always) an increased frequency of chromosomal aneuploidies [42]. Indeed, a man identified with a 14-fold higher frequency of XY disomy in 
his spermatozoa than in controls produced a 47,XXY fetus with Klinefelter syndrome after ICSI [43]. A high rate of the disomic sex chromosome (i.e. XY) constitution in germ cells therefore bears the risk of getting a son with the same infertility syndrome. Additionally, there seems to be also a risk for novel aneuploidies in offspring of Klinefelter patients, like trisomy 21 [44]. Trisomy of chromosome 21 is not sex-linked and causes a mental retardation syndrome in male and female offspring as well; also called Down's syndrome (see website: http://www3.ncbi.nlm.nih.gov/htbinpost/Omim/dispmim?190685).

Since in a compromised testicular environment an increase of meiotic errors is expected in general [25, 45], a FISH analysis on all chromosomes in the sperm nuclei would be the state of art, if one wants to minimise the risk of any chromosome aneuploidies in the offspring. Additionally, it would also help to reduce the risk for implantation failure or for an early abortion of the pregnancy due to some abnormal chromosome segregations in the early embryo. Most chromosome aneuploidies are embryonic lethal and only aneuploidies of the sex chromosomes and the chromosomes 13,14, 16, 18, 21, 22 have a chance to be transmitted to the offspring. Therefore, markers for these chromosomes should be included first in any FISH probe cocktail.

Theoretically, a balanced chromosomal translocation in the lymphocytes of one parent has a risk of $50 \%$ to become unbalanced in the offspring. However, all chromosome abnormalities are generally counter-selected by the meiotic segregation mechanisms [26], and translocation chromosomes are expected with a variable frequency in the postmeiotic germ cells. Robertsonian translocation chromosomes were found with a frequency between 3-27\% for an unbalanced karyotype in postmeiotic germ cells by FISH and karyotype sperm analyses [32]. Therefore, although there is a general risk for an unbalanced karyotype in the patients' offspring, its individual frequency can only be identified by FISH in the germ cells of the patient directly. In case of a high frequency, preimplantation diagnosis (PGD) of the blastomere chromosomes is required screening for the same chromosome anomaly.

Structural chromosome aberrations can be analysed by FISH in spermatozoa, after the chromosome location of the genomic rearrangement has been mapped from the metaphase chromosomes of the patient's lymphocytes. FISH probes are then designed according to the identified chromosomal breakpoint-fusionpoints with a breakpoint overlapping BAC clone extracted from the GenBank database. The complete human genome sequence is now deposited in the internet-web as an overlapping BAC sequence contig (see website:http://www.ncbi.nlm.nih.gov/genome/guide/human).

An attractive alternative of the FISH analyses on sperms would be a FISH on the patients' meiotic chromosomes in pachytene spermatocytes extracted from the patients' testicular biopsies [46, 47]. A FISH sperm analysis may then not be needed because the risk for sperm chromosome aneuploidies can be deduced from the severity of the observed distortions in the meiotic chromosomes segregation pictures. Studies on meiotic chromosomes extracted from testicular biopsies would save all mature sperm cells for the subsequent ICSI treatments and therefore have a general benefit, especially for all those patients with a low sperm number and OAT syndrome [33, 34].

From the first large comparative study of germ cell chromosome analyses with later prenatal chromosome analyses in the corresponding ICSI offspring, it has been now established that ICSI offspring have an increased risk for chromosomal abnormalities, especially for those with sex chromosomes. This risk seems to correlate with number and motility of the fathers' germ cells and their frequency of chromosome abnormalities [39]. The same major outcome was also predicted from a large data collection of earlier germ cell chromosome studies [22]. Moreover, it is advisable to include a preimplantation diagnosis (PGD) for any case with a significant risk of sperm cell chromosome aneuploidies, like patients with Klinefelter syndrome. PGD offers the couple to choose then a female embryo or male embryo with a normal karyotype for subsequent implantation. A later prenatal diagnosis with the option of abortion can be a second option.

\section{MOLECULAR ABERRATIONS WHICH CAUSE MALE INFERTILITY}

From mouse knock-out models it has been predicted that more than 3000 genes expressed in the male (and female) germ line cause infertility or at least subfertility [3, 4]. However, although most of their human homologues are known, it is often unclear whether and how these genes are functional in the human male germ line. When rodent and human gene sequences are compared, many reproductive genes are found among the $10 \%$ most divergent gene sequences [48] which indicates a rapid evolution of just reproductive proteins [49]. Consequently, it must be questioned, whether functional human spermatogenesis studies should be not better carried out directly with the human male fertility genes? However, the common mutation rates of human genes have been estimated to be in the range of $10^{-4}-10^{-6}[50]$ and that is certainly also true for the male fertility genes. Accordingly, for most of the putative human male fertility genes where mouse homologues exist and where knock-out mutants have displayed a reproductive disorder, it is not yet known how frequent the human genes are mutated in the large group of patients with idiopathic infertility, despite two notable exceptions: Deletions of the AZoospermia Factor (AZF) genes located on the long arm of the $\mathrm{Y}$ chromosome (Yq11) and mutations in the Cystic Fibrosis (CF) locus located on the long arm of chromosome 7 (7q31.2). AZF gene deletions are found most frequently in patients with non-obstructive azoospermia [51, 52], whereas CF mutations are abundantly found in patients with a congenital aplasia of the vas deferens (CBAVD), i.e. with obstructive azoospermia [53]. Molecular genetic research on human male fertility genes is therefore often only practical for those genes with a high mutation rate, since human is not an experimental species.

\section{THE AZF LOCUS IN YQ11}

Most Y chromosomal rearrangements with a breakpoint in Yq11 have been associated with distortion of male fertility "Fig. (2)". This suggested a spermatogenesis locus in this Y region already 27 years ago [54]. Because the sterile pheno- 
type observed in these patients was mostly azoospermia, this locus was designated as AZoospermia Factor (AZF). Molecular deletion mapping in Yq11 has then subdivided $\mathrm{AZF}$ in three spermatogenesis loci (AZFa, AZFb, AZFc) "Fig. (3A)". Their deletion interrupted spermatogenesis at three different phases [15]. A complete Sertoli-cell-onlysyndrome (SCO) is observed in patients with deletion of AZFa, i.e. only Sertoli cells, but no germ cells are visible in the tubules of their testis tissue sections Arrest at the spermatocyte stage is observed in the testis tissue of all patients with deletion of the complete $\mathrm{AZFb}$ locus (AZFb). The populations of spermatogonia and primary spermatocytes in all tubules analysed are normal, however, no postmeiotic germ cells have been identified A variable testicular pathology has been found in patients with AZFc deletions in distal Yq11. In most tubules only Sertoli cells are identified but in some tubules germ cells of different developmental stages are clearly visible "Fig. (3B)" and the occurrence of mature sperm cells albeit in a low number has been also reported from different laboratories [55, 56]. Hypospermatogenesis seems therefore to be the primary result of an AZFc deletion [51] and it is not surprising that AZFc deletions can also be inherited from father to son although only in rare cases [56-59].

It has been also argued that the patient's AZFc deletion does not cause his infertility [60]. More likely this would be a polymorphic deletion event present in the patient's family. However, most AZFc deletions are found as "de novo" mutations, i.e., being restricted to the patient's Y chromosome and not present on the Y chromosome of other family members, which would be expected if the deletion would have a polymorphic origin. Consequently, AZFc deletions must be causative agents of the men's infertility. They occur in different populations with a frequency of 10$20 \%[51,52,61,62]$ and are therefore now acknowledged as the most common known genetic lesion found in men with non-obstructive azoospermia or severe oligozoospermia.

It has been shown that microdeletions on autosomes are caused by local recombinations between repetitive homologous sequence blocks [63] and this is also the case for the AZF microdeletions on the human $\mathrm{Y}$ chromosome. Analysis of the complete $\mathrm{Y}$ sequence, now published in GenBank database [64] has revealed that the Yq11 part of the long arm is largely composed of $\mathrm{Y}$-specific repetitive sequence blocks especially in the $\mathrm{AZFc}$ deletion interval [65]. Intrachromosomal recombination events between repetitive specific HERV (Human Endogenous Retroviral) sequence blocks are now known as the major cause of AZFa deletions [66-68] and the molecular extension for complete AZFa deletions has been estimated with $782 \mathrm{~kb}$. Similarly, recombinations between large homologous sequence blocks composed of different repetitive sequence families are the major cause of complete $\mathrm{AZFb}$ and $\mathrm{AZFc}$ deletions and their molecular extension is estimated with $6.2 \mathrm{Mb}(\mathrm{AZFb})$ and 3.5 Mb (AZFc), respectively [65, 69] "Fig. (3C)". Whereas the $\mathrm{AZFb}$ deletion interval also contains a large sequence block with normal euchromatic sequence complexity (designated as $\mathrm{u} 1: \sim 3 \mathrm{Mb}$ ), about $94 \%$ of the AZFc sequence complex are covered with unusually large repetitive sequence blocks. They are called amplicons [65] with variable length, between $115 \mathrm{~kb}$ (grey amplicons) and $700 \mathrm{~kb}$ (yellow amplicons) and explain the high mutation rate for the AZFc locus in distal Yq11.

Most intriguing is the structural assembly of these large repetitive sequence blocks in 5 palindrome structures (P1$\mathrm{P5}$ ) in the AZFb and AZFc deletion intervals "Fig. (3C)". In distal AZFc, the $3 \mathrm{Mb}$ large palindrome structure (P1palindrome) which covers two-third of the complete AZFc deletion interval is constituted of 5 different amplicons "Fig. (3C)". The sequence homology of the palindrome arms is $>99.9 \%[65,69]$. The distal part of the AZFb deletion interval and the proximal part of the AZFc deletion interval are overlapping and the 4 palindromes P2-P5 are mapped, from distal to proximal (towards the $\mathrm{Y}$ centromere) in distal $\mathrm{AZFb}(\mathrm{P} 2: 270 \mathrm{~kb}, \mathrm{P} 3: 730 \mathrm{~kb})$ and in proximal AZFb (P4: $380 \mathrm{~kb}$ P5: $900 \mathrm{~kb}$ ) respectively "Fig. (3C)". Palindromic DNA structures are rare in eukaryotic genomes because of their inherent instabilities [70]. Consequently, local homologies between repetitive sequence blocks in P1 and the $\mathrm{P} 5$ palindromes in proximal $\mathrm{AZFb}$ have led to most $\mathrm{AZFb}$ deletions "Fig. (3C)". It is important to recognise that patients with deletions of the AZFb plus AZFc interval have not deleted the complete AZFc sequence as defined by Kuroda-Kawaguchi et al. but their AZFc deletion ends in the distal arm (P1.1) of the P1 palindrome "Fig. (3C)". Its molecular extension was estimated with 7.7 Mb [69]. AZFc deletions are caused by homologous recombination between the $229 \mathrm{~kb}$ long b2 and b4 amplicons [69] although one may speculate that the large P1 palindrome is also actively involved in the creation of these recombination events.

The genomic DNA of each AZF deletion interval contains multiple genetic elements which are probably functional parts of the AZF locus. Extensive testes cDNA screening programs [71, 72], and the structural analysis of the the GenBank AZF sequences (AZFa and AZFb in contig: NT_011875; AZFc in contig: NT_011903) by predictive gene analyses programs have identified the putative complete gene content of each AZF microdeletion. $32 \mathrm{Y}$ genes expressed in human testis and located in one of the AZF deletion intervals are registered. They are subdivided in Table $\mathbf{1}$ in a list of genes with a recognizable function because of one or more conserved functional peptide domains (Table 1A) and in a list of genes with non-identified function because similar sequences have not yet been found in the data base (Table 1B). AZFa contains 2 Y genes: USP9Y and DBY, and it might include functionally the UTY gene mapped closely to the distal AZFa HERV border line because the same gene triplet has been found structurally conserved on the mouse and cat Y chromosomes [73]. AZFb which overlaps with the proximal part of AZFc contains 23 putative functional $\mathrm{Y}$ genes [69]: $16 \mathrm{Y}$ genes were mapped in the unique AZFb interval: CDY2, CYorf14, CYorf15A/B, EIF1AY, HSFY, PRY, RBMY1, RPS4Y2, SMCY, TTY5, TTY6, TTY9, TTY10, TTY13, TTY14, XKRY (Table 1). The $\mathrm{Y}$ genes designated with a CYorf symbol are coding proteins with unknown functions whereas the genes designated with a TTY symbol are declared as putative RNA coding genes because their exon sequences apparently have no significant open reading frame [71]. $3 \mathrm{AZFb}$ genes (CDY2, RPS4Y2, XKRY) have more copies also proximal to $\mathrm{AZFb}$ and the $7 \mathrm{AZFb}$ genes which are located in the 


\section{Molecular map of the 3 AZF loci on human Y chromosome}

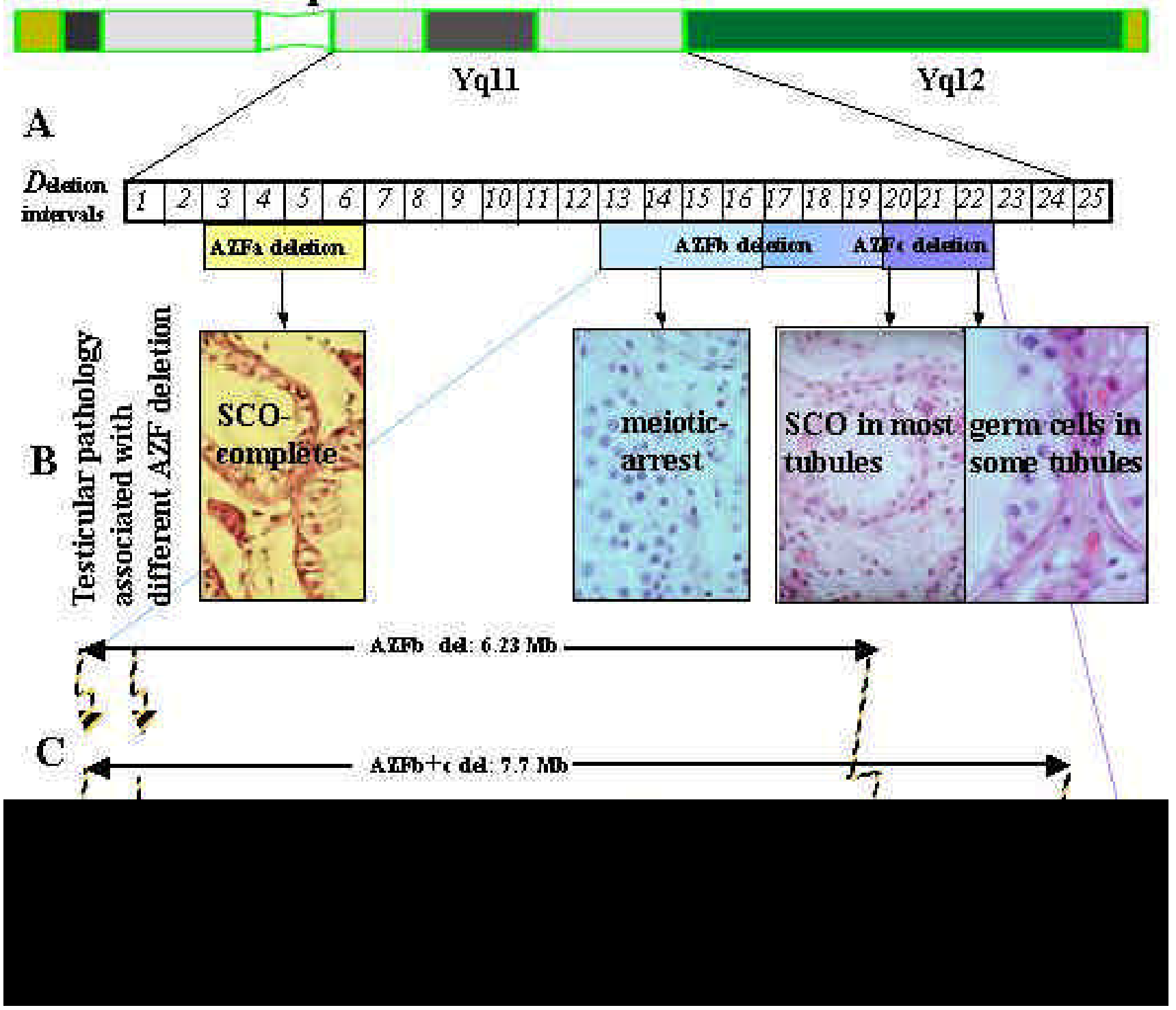

Fig. (3). Molecular map of the 3 AZF loci on the human Y chromosome in Yq11. (A): With aid of a series of Y-specific probes and STSs the long $\mathrm{Y}$ arm (Yq 11) has been subdivided in 25 molecular deletion intervals (D1-D25) [56]. Interval D25 correspond to the Yq12 heterochromatin. The $D$ intervals deleted in infertile patients with complete AZFa, AZFb, and AZFc deletions are drawn with a specific colour code below the interval map. In contrast to the first AZF interval map in Vogt et al. [56], molecular sequence analyses have now revealed a large overlap of the AZFb and AZFc deletion intervals [69], and AZFb deletions extend approximately until interval D21. (B): Examples of the associated testicular pathologies are displayed below the AZF deletion map. Patients with complete AZFa deletions have always a complete absence of germ cells Patients with complete AZFb deletions usually show a meiotic arrest at pachytene whereas patients with complete AZFc deletions display a variable picture with a "mixed atrophy" in their testis tubules. Most tubules have a SCO, but some tubules contain also germ cells at different phases of differentiation. (C): Comparative view on the schematic AZFb and AZFc deletion intervals with their underlying genomic sequence structure now revealed by Kuroda-Kawaguchi et al. [65] and Repping et al. [69]. Molecular extensions of the estimated AZFb, AZFc and AZFb plus AZFc deletions are given in $\mathrm{Mb}$. The five possible palindromic structures P1-P5 in this Yq11 region are marked each with the extensions of both arms below the amplicon structure in a similar colour code as used for the corresponding amplicons. Only the large P1 palindrome and the P3 palindrome include more than one amplicon type. The AZFb deletion overlaps with the AZFc deletion as indicated. The putative AZFb break and fusion points are marked by yellow arrows because they are mediated by recombinations between the homologous yellow amplicons, yel1, yel3 and yel4, respectively, in the first (P1.2 arm) and fifth palindrome (P5.1 and P5.2 arm). AZFc break and fusion points are marked by blue arrows because they are mediated by recombinations between the blue amplicons, b2 and b4. In patients with an AZFb plus AZFc deletion the distal breakpoint was found to be not in the b4 amplicon (as expected) but in the yellow amplicon yel2 (P1.1 palindrome arm) [69]. 
Table 1A. Human Y Genes with Known Function Mapped in AZFa, AZFb and AZFc Deletion Intervals ${ }^{1}$

\begin{tabular}{|c|c|c|c|c|c|c|c|c|}
\hline $\begin{array}{l}\text { Gene } \\
\text { symbol }\end{array}$ & Gene name & $\begin{array}{c}\text { Number of } \\
\text { copies and code }\end{array}$ & $\begin{array}{c}\text { Protein } \\
\text { homolog to }\end{array}$ & $\begin{array}{c}\text { Tissue RNA } \\
\text { expression }\end{array}$ & $\begin{array}{c}\text { Copies in } Y p \\
\text { interval ? }\end{array}$ & Yq11 interval & $\begin{array}{c}\text { X chromosome } \\
\text { homolog }\end{array}$ & $\begin{array}{c}\text { Autosome } \\
\text { homolog }\end{array}$ \\
\hline BPY2 & $\begin{array}{l}\text { Basic Protein } \\
\text { Y, pI } 10\end{array}$ & BPY2.1-3 & Novel & only testis & no & $\mathrm{AZFc}$ & no & \\
\hline $\begin{array}{l}\text { CDY1 } \\
\text { CDY2 }\end{array}$ & $\begin{array}{c}\text { Chromo } \\
\text { Domain Y1/2 }\end{array}$ & $\begin{array}{l}\text { CDY1.1-2 } \\
\text { CDY2.1-2 }\end{array}$ & $\begin{array}{l}\text { Chromatin } \\
\text { Package } \\
\text { protein }\end{array}$ & $\begin{array}{l}\text { only testis } \\
\text { only testis }\end{array}$ & no & $\begin{array}{c}\text { AZFb } \\
+ \text { Yq11-D11 } \\
(\mathrm{CDY} 2) \\
\text { AZFc (CDY1) }\end{array}$ & no & $\begin{array}{l}\text { 6p24; } \\
\text { CDYL }\end{array}$ \\
\hline CSPG4LY & $\begin{array}{l}\text { Chondroitin sulfate } \\
\text { proteoglycan } \\
\text { 4 Like Y }\end{array}$ & CSPG4LY.1-2 & cadherins & only testis & no & $\mathrm{AZFc}$ & no & $\begin{array}{l}15 \mathrm{q} 24 ; \\
\text { CSPG4 }\end{array}$ \\
\hline DAZ & $\begin{array}{c}\text { Deleted in } \\
\text { Azoospermia }\end{array}$ & $\begin{array}{l}\text { DAZ1, DAZ2, } \\
\text { DAZ3, DAZ4 }\end{array}$ & $\begin{array}{l}\text { RNA binding } \\
\text { RRM proteins }\end{array}$ & only testis & no & $\mathrm{AZFc}$ & no & $\begin{array}{c}3 \mathrm{p} 24 \\
\text { DAZL1 }\end{array}$ \\
\hline DBY & DEAD Box Y & 1 & RNA helicases & multiple ${ }^{2}$ & no & $\mathrm{AZFa}$ & yes; DBX & \\
\hline EIF1AY & $\begin{array}{c}\text { Essential Initiation } \\
\text { Translat. } \\
\text { Factor 1A Y }\end{array}$ & 1 & $\begin{array}{l}\text { Translation } \\
\text { Initiation } \\
\text { Factor }\end{array}$ & multiple & no & $\mathrm{AZFb}$ & yes, EIF1AX & \\
\hline $\begin{array}{l}\text { GOLGA } \\
2 \mathrm{LY}\end{array}$ & $\begin{array}{l}\text { Golgi autoantigen, } \\
\text { golgin Subfamiliy } \\
\text { a2 Like Y }\end{array}$ & $\begin{array}{c}\text { GOLGA2LY } \\
1-2\end{array}$ & $\begin{array}{l}\text { CIS GOLGI } \\
\text { Matrix Protein } \\
\text { GM130 }\end{array}$ & only testis & no & $\mathrm{AZFc}$ & no & $\begin{array}{c}\text { 9q34; } \\
\text { GOLGA2 }\end{array}$ \\
\hline HSFY & $\begin{array}{c}\text { Heat-Shock } \\
\text { transcription } \\
\text { Factor Y linked }\end{array}$ & HSFY.1-2 & HSP- 2 like & testis, kidney & no & $\mathrm{AZFb}$ & no & $\begin{array}{l}6 q 22 \\
\text { HSP2 }\end{array}$ \\
\hline PRY & $\begin{array}{l}\text { PTP - BL } \\
\text { Related Y }\end{array}$ & PRY.1-2 & $\begin{array}{c}\text { Protein } \\
\text { Tyrosin } \\
\text { Phosphatase }\end{array}$ & only testis & $\begin{array}{c}\text { prox. Yp11 } \\
\text { pseudogenes }\end{array}$ & $\begin{array}{c}\text { AZFb } \\
\text { AZFc: } \\
\text { pseudogenes }\end{array}$ & no & \\
\hline RBMY & $\begin{array}{l}\text { RNA Binding } \\
\text { Motif Y-linked }\end{array}$ & RBMY1.1-6 & $\begin{array}{l}\text { RNA binding } \\
\text { RRM - } \\
\text { Proteins }\end{array}$ & only testis & $\begin{array}{l}\text { prox. Yp11 } \\
\text { pseudogenes }\end{array}$ & $\begin{array}{c}\text { AZFb } \\
\text { AZFc: } \\
\text { pseudogenes }\end{array}$ & RBMX & \\
\hline RPS4Y2 & $\begin{array}{l}\text { Ribosomal } \\
\text { Protein S4 } \\
\text { Y linked } 2\end{array}$ & 1 & $\begin{array}{l}\text { S4 ribosomal } \\
\text { protein }\end{array}$ & multiple & $\begin{array}{c}\text { distal Yp11 } \\
\text { RPS4Y1 }\end{array}$ & $\mathrm{AZFb}$ & yes; RPS4X & \\
\hline SMCY & $\begin{array}{c}\text { Selected Mouse C } \\
\text { DNA Y }\end{array}$ & 1 & $\begin{array}{c}\text { H - Y antigen } \\
\text { HLA B7 }\end{array}$ & multiple & no & $\mathrm{AZFb}$ & yes; SMCX & \\
\hline $\begin{array}{l}\text { USP9Y } \\
\text { DFFRY }\end{array}$ & $\begin{array}{c}\text { Drosophila Fat } \\
\text { Facets } \\
\text { Related Y }\end{array}$ & 1 & $\begin{array}{l}\text { Ubiquitin- } \\
\text { specific } \\
\text { protease }\end{array}$ & multiple & no & $\mathrm{AZFa}$ & $\begin{array}{l}\text { yes; DFFRX } \\
\text { USP9X }\end{array}$ & \\
\hline UTY & $\begin{array}{c}\text { Ubiquitous } \\
\text { Transcribed Y }\end{array}$ & 1 & $\begin{array}{c}\mathrm{H}-\mathrm{Y} \text { antigen } \\
\mathrm{HYD}^{\mathrm{b}}\end{array}$ & multiple & no & $\mathrm{AZFa}$ & yes; UTX & \\
\hline XKRY & $\begin{array}{l}\text { X - Kell blood } \\
\text { group precursor } \\
\text { related Y }\end{array}$ & XKRY.1-2 & $\begin{array}{l}\text { putative } \\
\text { membrane } \\
\text { transport } \\
\text { protein }\end{array}$ & only testis & no & $\begin{array}{c}\mathrm{AZFb}+\mathrm{Yq} 11- \\
\mathrm{D} 11\end{array}$ & no & \\
\hline
\end{tabular}

${ }^{1}$ according to Vogt et al., (1997) in ref. 72; Kuroda-Kawaguchi et al., (2001) in ref. 65; Repping et al. (2002) in ref. 69; Skaletzky et al., (2003) in ref. 247.

${ }^{2}$ additional RNA populations with smaller lengths were found only in testis tissue (Lahn and Page, 1997 in ref.71) 
Table 1B. Human Y-Genes in AZFb and AZFc with and Without Putative Protein Coding Potential ${ }^{1}$

\begin{tabular}{|c|c|c|c|c|c|c|}
\hline $\begin{array}{c}\text { Gene } \\
\text { symbol }\end{array}$ & $\begin{array}{l}\text { Gene } \\
\text { name }\end{array}$ & $\begin{array}{c}\text { Protein } \\
\text { homolog to }\end{array}$ & $\begin{array}{c}\text { Tissue RNA } \\
\text { expression }\end{array}$ & $\begin{array}{l}\text { Copies in } \\
\text { Yp interval }\end{array}$ & $\begin{array}{c}\text { Yq11 } \\
\text { interval }\end{array}$ & $\begin{array}{c}\text { X chromosome } \\
\text { homolog }\end{array}$ \\
\hline CYorf15A & $\begin{array}{c}\text { Chromosome } \mathrm{Y} \\
\text { openreading frame } 15 \mathrm{~A}\end{array}$ & unknown & multiple & no & $\mathrm{AZFb}$ & yes; cXorf 15 \\
\hline CYorf15B & $\begin{array}{c}\text { Chromosome Y } \\
\text { openreading frame 15B }\end{array}$ & unknown & multiple & no & $\mathrm{AZFb}$ & yes; cXorf 15 \\
\hline TTY1 & Testis Transcript Y1 & $\begin{array}{l}\text { no-protein } \\
\text { encod. RNA }\end{array}$ & only testis & prox. Yp11 & no & no \\
\hline TTY2 & Testis Transcript Y2 & $\begin{array}{l}\text { no-protein } \\
\text { encod. RNA }\end{array}$ & only testis & prox. Yp11 & $\mathrm{AZFb}$ & no \\
\hline TTY3 & Testis Transcipt Y3 & $\begin{array}{l}\text { no-protein } \\
\text { encod. RNA }\end{array}$ & only testis & no & $\mathrm{AZFc}$ & no \\
\hline TTY4 & Testis Transcript Y4 & $\begin{array}{c}\text { no-protein } \\
\text { encod. RNA }\end{array}$ & only testis & no & $\mathrm{AZFc}$ & no \\
\hline TTY5 & Testis Transcipt Y5 & $\begin{array}{l}\text { no-protein } \\
\text { encod. RNA }\end{array}$ & only testis & no & $\mathrm{AZFb}$ & no \\
\hline TTY6 & Testis Transcript Y6 & $\begin{array}{l}\text { no-protein } \\
\text { encod. RNA }\end{array}$ & only testis & no & $\mathrm{AZFb}$ & no \\
\hline TTY9 & Testis Transcript Y 9 & $\begin{array}{c}\text { no-protein } \\
\text { encod. RNA }\end{array}$ & only testis & no & $\mathrm{AZFb}$ & no \\
\hline TTY10 & Testis Transcipt Y10 & $\begin{array}{l}\text { no-protein } \\
\text { encod. RNA }\end{array}$ & only testis & no & $\mathrm{AZFb}$ & no \\
\hline TTY12 & Testis Transcipt Y12 & $\begin{array}{c}\text { no-protein } \\
\text { encod. RNA }\end{array}$ & only testis & no & $\mathrm{AZFb}$ & no \\
\hline TTY13 & Testis Transcript Y13 & $\begin{array}{l}\text { no-protein } \\
\text { encod. RNA }\end{array}$ & only testis & no & $\mathrm{AZFb}$ & no \\
\hline TTY14 & Testis Transcipt Y14 & $\begin{array}{l}\text { no-protein } \\
\text { encod. RNA }\end{array}$ & only testis & no & $\mathrm{AZFb}$ & no \\
\hline $\begin{array}{c}\text { TTY15 } \\
\text { AZFaT1 }^{2} \\
\text { Phex } 152^{3}\end{array}$ & Testis Transcipt Y15 & $\begin{array}{l}\text { no-protein } \\
\text { encod. RNA }\end{array}$ & testis, brain & no & AZFa & no \\
\hline TTY17 & Testis Transcript Y17 & $\begin{array}{l}\text { no-protein } \\
\text { encod. RNA }\end{array}$ & only testis & no & $\mathrm{AZFc}$ & no \\
\hline TTY16 & Testis Transcipt Y16 & $\begin{array}{l}\text { no-protein } \\
\text { encod. RNA }\end{array}$ & only testis & no & $\mathrm{AZFb}$ & no \\
\hline
\end{tabular}

${ }^{1}$ according to Kuroda-Kawaguchi et al., (2001) in ref. 65; Repping et al. (2002) in ref. 69; Skaletzky et al., (2003)

in ref. 247. Although Skaletzky et al. described 23 TTY genes (TTY1-TTY23) only the 14 listed here are mapped on the Y chromosome sequence.

${ }^{2}$ Sargent et. Al. (1999) in: J.Med. Genet. Vol. 36: 670-677.

${ }^{3}$ Ditton, Hirschmann, Vogt (1999) unpublished results.

AZFb-AZFc overlapping interval (BPY2.1, CDY1.1, DAZ1, DAZ2, TTY3.1, TTY4.1, TTY17.1) have more copies distal to $\mathrm{AZFb}$ in the unique part of the $\mathrm{AZFc}$ deletion interval "Fig. (3C)". Thus most AZFc gene families have a copy in the AZFb deletion interval (BPY2, CDY1, DAZ, TTY3, TTY4, TTY17) and only the CSPG4LY and GOLGA2LY gene families are located in the unique part of AZFc. This might explain the more severe testicular pathology associated with complete $\mathrm{AZFb}$ deletions when compared with the testicular pathology of men with only a pure AZFc deletion. AZFb deletions include deletion of $13 \mathrm{Y}$ genes completely and of $10 \mathrm{Y}$ genes partially with more copies located proximal and distal to the $\mathrm{AZFb}$ deletion interval, whereas AZFc deletions only include the deletion of $8 \mathrm{Y}$ gene families. 
It has been reported that also men with $\mathrm{AZFa}$ and $\mathrm{AZFb}$ deletions present a variable testicular histology [74-76]. However, the molecular extensions of these Y deletions are now known to be not comparable with that of the originally defined AZFa and AZFb deletion intervals [56] and in cases where a re-analysis was possible only partial AZFa and $\mathrm{AZFb}$ deletions have been identified $[61,67,77]$.

Interestingly, all AZFa genes and most $\mathrm{AZFb}$ genes have an $\mathrm{X}$ chromosomal counterpart, and some of them are conserved on the mouse Y chromosome (Dby, Smcy, Rbm, Uty, Usp9y). However, so far analysed their function in mouse spermatogenesis looks different from that in human spermatogenesis. In mouse, Usp9y is expressed in brain and testis tissue [78], whereas the human homolog USP9Y is expressed in all tissues analysed [71]. In mouse, deletion of most Rbm genes does not cause male infertility but only some sperms dysmorphologies [79]. In human, RBM genes are expressed during meiosis and their deletion causes meiotic arrest [80]. In mice with deletion of the Spy locus (mapped in the Sxrb interval of the short Y arm), expression of the Eif $2 y$ gene restores the proliferation phase of spermatogonia suggesting that Eif2y is the functional gene of the Spy locus [81]. In human, there is no homologous EIF2Y gene on the $\mathrm{Y}$ chromosome. It is therefore assumed that the human $\mathrm{AZFa}$ and $\mathrm{AZFb}$ genes and their homologous counterparts on the mouse $\mathrm{Y}$ chromosomes are functionally related but not orthologs in the male germ line of both species, i.e., their spermatogenic functions are divergent, respectively, adopted to the species specific needs, although most likely part of the same functional genetic network [82].

The AZFc locus can be considered as an evolutionarily very young human spermatogenesis locus because no AZFc gene family has been found on the mouse $\mathrm{Y}$ chromosome. The DAZ gene family has been transposed from the DAZL1 locus on chromosome 3 (3p25) to the Y chromosome after divergence of the Old world monkey line of primates, i.e., not before about 35 million years ago [83, 84]. The CDY gene family originates from a polyadenylated mRNA of the CDYL locus on chromosome 6 which has been then retrotransposed to the $\mathrm{Y}$ chromosome also first after divergence of the Old world monkey line of primates [85].

\section{Do AZF Gene Mutations Cause Male Infertility?}

It is still an open question whether infertility is caused in men only after deletion of the complete gene content in one of the AZF loci, or also after deletion or dysfunction of a specific AZF gene as well. Until now, an AZF gene mutation probably associated with the occurrence of male infertility has been only found for the USP9Y gene in AZFa. After sequence analysis of the USP9Y sequence in 564 patients with azoospermia or severe oligozoospermia, a 4 bp deletion as part of the splice-donor site of exon 8 was identified as "de novo" mutation in one patient with spermatid arrest [86]. This suggests a functional contribution of USP9Y to human spermatogenesis. However, the AZFa pathology, is a complete SCO syndrome. Expression of the DBY gene or other genetic factors in AZFa must therefore also contribute to the AZFa spermatogenic function.

A similar situation might be present in $\mathrm{AZFb}$ where partial proximal AZFb deletions not including the PRY and
RBMY gene loci but proven to be "de-novo" deletion events were associated with hypospermatogenesis [77], whereas complete $\mathrm{AZFb}$ deletions cause a complete meiotic arrest. However, since also a SCO and natural transmission was described for some of the partial-AZFb patients [77, 87], impairment of the testicular function in this patient group seems variable and reflecting some linkage with other spermatogenesis genes located on different still unknown chromosomal sites. Gene-specific mutations in the RBMY gene locus were found in fertile men and infertile men, revealing a polymorphic number of pseudogenes in this $\mathrm{AZFb}$ gene family [88].

Specific mutations in a gene of the AZFc gene families are difficult to map because the multiple copies of all AZFc genes have an extremely high sequence homology $>99.9 \%$ [65]. A functional difference between genes mapped in proximal and distal $\mathrm{AZFc}$, respectively, might be indicated by the work of Fernandes et al. [89], who found deletions of the DAZ1/DAZ2 gene doublet in proximal AZFc only in men with severe oligozoospermia, but DAZ3 and DAZ4 deletions in men with normal fertility as well. It could be shown that these proximal AZFc deletions are caused by recombinations between the $\mathrm{g} 1 / \mathrm{g} 2$ amplicons in AZFc "Fig. (3C)". The Y chromosome of patients with a DAZ1/DAZ2 deletion would therefore also have a deletion of the proximal copies of the BPY2, CDY1, CSPG4LY, GOLGA2LY, TTY3, TTY4, and TTY17 gene loci (BPY2.1, CDY1.1, CSPG4LY.1, GOLGA2LY.1, TTY3.1, TTY4.1, TTY17.1). Stuppia et al. reported of a family where the Y chromosome of the fertile father had a deletion in distal AZFc, which then was enlarged in the $\mathrm{Y}$ chromosome of the infertile son towards proximal AZFc [90]. Only gene families have been mapped in AZFc. It might therefore be assumed that the AZFc locus is genetically redundant and that distal AZFc deletions are compatible with normal male fertility.

Recently, some peptides encoded from AZFa and AZFb genes (USP9Y, DBY, UTY, and SMCY) were identified as putative male specific minor histocompatibility antigens $(\mathrm{H}-$ $\mathrm{Y}$ antigens) recognised from gene products encoded in different classes of the large Major Histocompatibility Locus (MHC) on the short arm of chromosome $6(3.6 \mathrm{Mb}$ in 6p21.3) [91]: the HLA-A1 class (USP9Y) [92], the HLADQ5 class (DBY) [93], the HLA-B8 and -B60 class [UTY; 94, 95] and the HLA-B7 and -A2 class (SMCY) [96, 97]. Indeed, the influence of some $\mathrm{H}-\mathrm{Y}$ antigens on human (and mouse) testicular organisation and spermatogenesis has long been predicted [98] and molecular deletion mapping has localised an H-Y antigen locus on the human Y chromosome in the proximal part of the long $\mathrm{Y}$ arm [99] overlapping with the AZFa and AZFb intervals "Fig. (3A)". The only receptor for $\mathrm{H}-\mathrm{Y}$ antigens was identified in the membranes of Sertoli cells [98] and their expression revealed in early embryogenesis [100]. Y chromosomal H-Y antigens might therefore be considered as early male-specific cell markers probably contributing as positive signals for the first steps of male sexual and germ line development during early embryogenesis. Whether the deletion of any of those linked to the $\mathrm{Y}$ genes in $\mathrm{AZFa}$ and $\mathrm{AZFb}$ are associated with the occurrence of male infertility is difficult to assess but can also not be excluded. 


\section{ICSI Transmission of AZFc Deletions can Cause Severe Gonadal Dysgenesis in Offspring}

Using sperms of AZFc patients in ICSI a $100 \%$ transmission of the AZFc deletion to the male offspring has been reported [101-103]. That means the sons of AZFc patients will become infertile as well. However, additionally, there seems to be a risk for AZFc offspring to get some forms of gonadal dysgenesis or even sexual reversal as well. There is some growing evidence that the complete loss of the $\mathrm{Y}$ chromosome causing embryonic $45, \mathrm{X} 0$ cells is triggered by $\mathrm{AZFc}$ deletions as premutations. So a variable percentage of a 45,X0 cell line was found commonly associated with AZFc microdeletions [104, 105]. This is similar to the occurrence of patients with a cytogenetically visible iso-Yp chromosome where the Yq11 breakage-fusion events also have deleted the AZFc and most of the AZFb interval. A mosaic 45,X0 cell line occurs frequently in the karyotypes of this patient group as well "Fig. (2)". Indeed, a man with ambiguous genitalia, 45,X/46,XY mosaic karyotype and AZFc deletion has been already reported [106].

Now screening the $\mathrm{Y}$ chromosome of 12 patients, who had a 45X/46XY karyotype and presented with Turner stigmata and sexual ambiguities a high incidence of AZFc deletions was found in this patient group as well [107]. In an international survey of prenatally diagnosed 45X/46XY mosaicism a wide spectrum of phenotypes, including Turner syndrome, mixed gonadal dysgenesis, male pseudohermaphroditism, mild mental retardation, autism, but also normal men have been reported [108]. Therefore, it is wise to offer couples where fathers had an AZF microdeletion a prenatal diagnosis (PGD) for revealing a putative mosaic 45X/46XY karyotype in the fetus as early as possible.

\section{THE CF-LOCUS IN 7Q31.2}

In contrast to the $\mathrm{AZF}$ locus, the functional picture of the $\mathrm{CF}$ (Cystic fibrosis) locus is much more elucidated. The locus encodes the Cystic Fibrosis Transmembrane conductance Regulator (CFTR) gene which is functioning as a lowvoltage, cyclic-AMP-regulated transmembrane channel for chloride ions [109]. The CFTR protein is a member of the ATP-binding cassette (ABC) familiy of transporter proteins. CFTR gene defects cause cystic fibrosis (CF) which is mainly characterised by persistent Pseudomonas aeruginosa colonization of the conducting airways. CFTR gene mutations were divided in 6 classes (I-VI) and two major categories. The first category includes those mutants where the CFTR protein is unable to accumulate at the cell surface, either because of impaired biosynthesis (Class I and V), or because of defective folding at the endoplasmic reticulum (Class II). Mutants that belong to the second category express the CFTR protein at the cell surface but its mutated structure fails to translocate chlorid ions because of a defect in activation (Class IV). CFTR class VI mutants appear to be normal in their biosynthetic processing and macroscopic chloride channel function but the biological stability of the mature, complex-glycosylated form is dramatically reduced [110]. Most frequently found in many populations (although not in all) is a deletion of 3 nucleotides in exon 10 which results in the loss of a phenylalanine residue at position 508 of the putative CFTR protein [111].
According to the CFTR online database (http://www. genet.sickkids.on.ca/cftr) a surprisingly high number of 1005 pathological CFTR mutations and 208 variants are registered, although most of them are rare and only present in single families. This suggests that the CFTR gene sequence can accommodate a certain variability without loss of his basic function: a protein with chlorid channel activity in the membranes of epithelial cells. It also indicates that the CFTR protein is embedded in a complex genetic network because the severity of the CF pathology associated with a specific gene mutation is variable in different pedigrees [112]. Depending on the CFTR mutation, the somatic disease phenotype is variable from severe pulmonary disease with pancreatic insufficiency to chronic bronchiectasis [113]. The high rate of heterozygous CFTR mutations in populations even suggests a functional benefit for at least some CFTR mutations. Indeed, it has been shown that cells expressing wildtype CFTR internalized more Salmonella typhi than isogenic cells expressing the most common del-F508 CFTR mutation [114]. Obviously, diminished levels of the CFTR protein in heterozygotes is of benefit because it decreases the susceptibility to typhoid fever.

Most common are CFTR mutations which manifest their cystic fibrosis pathology not only in somatic cells but also as a congenital bilateral aplasia of the vas deferens (CBAVD) in male gonads [53]. In this large patient group the transport of the mature spermatozoa through the testicular and epididymal structures is blocked [114]. The absence of the vas deferens and variable portions of the epididymis is most likely caused by excessive mucus secretions in the epididymal lumen which eventually then leads to a progressive obstruction of the deferent ductal system, i.e., the viscous epididymal fluid impairs the proper development of the epididymis, vas deferens and seminal vesicles [116]. The pathology of obstructive azoospermia occurs with about $30 \%$ in the group of patients with azoospermia, and of those $25 \%$ suffer from CBAVD.

CFTR mutations have usually only a recessive ${ }^{1}$ effect in somatic tissues [112]. In the germ line a dominant mutation effect is found, since only a small reduction of functional CFTR transcripts already causes male infertility [112], Consequently, it can be predicted that also a CBAVD patient group without the somatic CF pathology but with CFTR mutations must exist as well. The epithelial cells in the male genital tract appear to be more sensitive to a quantitative CFTR protein deficiency than the same cell type in other organs and also the processing of CFTR mutant transcripts might be different in the two cell types [117].

The most frequent CFTR mutation not causing CF but CBAVD is the 5T allele in the 3'splicing region of intron 8 [118]. In this region three $\mathrm{T}$ alleles $(5 \mathrm{~T}, 7 \mathrm{~T}, 9 \mathrm{~T})$ have been diagnosed. The reduction of the number of Ts results in reduction of the efficiency of splicing exon 9 in CFTR mRNA "Fig (4)". In the presence of the 5T allele only 10$40 \%$ of CFTR mRNA contains exon 9. Exon 9 encodes part of the functionally important first nucleotide binding domain.

\footnotetext{
${ }^{1}$ Recessive gene defect means $50 \%$ of the gene product is still sufficient for normal function (haplosufficiency); consequently dominant gene defects indicate that more than $50 \%$ of the gene product is necessary for normal cellular function.
} 


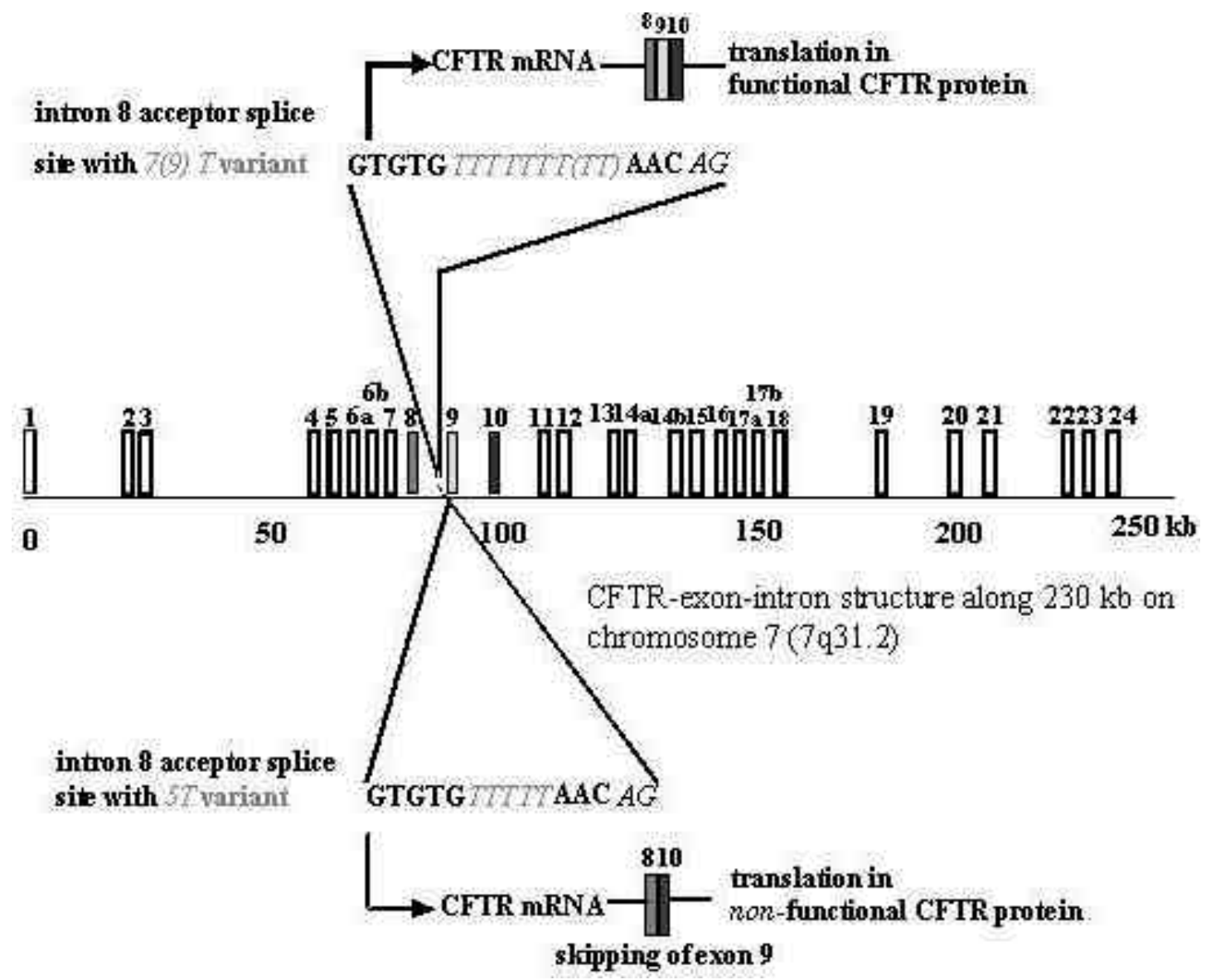

Fig. (4). Schematic view on the exon structure of the human Cystic Fibrosis Transmembrane Regulator (CFTR) gene located on the long arm of chromosome 7 (7q31.2) along $230 \mathrm{~kb}$. The variable number of $T$ nucleotides in intron 8 can result in skipping of exon 9 during the splicing process of CFTR primary transcripts. Translation of mRNAs without exon 9 results in a non-functional CFTR protein. Reduction of the number of T nucleotides is found especially in men with the CBAVD syndrome. For further discussion see text.

CBAVD is diagnosed in $1.5 \%$ of all cases of male infertility and a remarkable number $(60 \%)$ of heterozygous mutations in the CFTR gene form "compound heterozygotes" in the CBAVD patient group, i.e. different mutations in each gene copy are analysed [119]. Compound heterozygotes of CBAVD patients with a $5 \mathrm{~T}$ allele in one gene copy and a Arg117-to-His117 (R117H) mutation in exon 4 of the second gene copy have a severe CF phenotype, whereas the $7 \mathrm{~T}$ allele would only result in CBAVD [117].

Men with CBAVD have the 5T allele with a high frequency $(84 \%)$. This suggests that with this mutation numerous compound heterozygotes must exist expressing the CBAVD pathology. These were indeed found with some of the highly polymorphic sequence variants $(\mathrm{TG})_{\mathrm{m}}$ linked to the heterozygous M470V mutation [120]. Both variants have no deleterious consequences for the production of CFTR mRNA but in combination with the 5T allele the presence of these variants result in a high production of CFTR mRNA without exon 9 then causing the CBAVD pathology [121]. Probably there exists a general different processing of CFTR transcripts in the germ line since a higher proportion of CFTR-transcripts without exon 9 in vas deferens cells was also found independent of the $T_{n}$ genotype [122].
Since male and female carriers of a CFTR mutation are found very frequently in different caucasian populations (1:25), the female partners should be also analysed for a heterozygous CFTR mutation, after a CBAVD patient with a heterozygous or homozygous CFTR mutation has been identified. A heterozygous CFTR mutation in the female partner (carrier status), would predict a high risk (of at least $25 \%$ ) for the occurrence of a severe somatic CF pathology in the IVF offspring. Heterozygotic CFTR mutations are easily analysed by the amplification refractory mutation system (ARMS) which allows to distinguish the normal and mutant CFTR allele in parallel by a PCR based technology [123]. Alternatively, the low but measurable ectopic transcription rate of CFTR mRNA in lymphocytes can be used to identify CFTR mutations at the transcript level [124].

For the management of CFTR diagnostic quality control an European Network for cystic fibrosis genetic mutation analysis has now been established [125, 126: www. mwd.kuleuven.ac.be/cme/cf/genetic_diagnostic_labs.htm].

It has been reported that patients with obstructive azoospermia carrying a CFTR mutation had also significant lower seminal volumes $(1.5+/-1.4 \mathrm{ml}$ vs $2.8+/-2.2 \mathrm{ml})$, lower $\mathrm{pH}$ values (6.8 vs 7.9) and a lower fructose content (1-4 vs 6- 
83 micromol/ejaculate) than those without these mutations [127]. The analyses of seminal plasma markers therefore provides an effective and non-invasive method to predict CFTR mutations in men with obstructive azoospermia also from their ejaculates.

\section{MORE GENE MUTATIONS INTERFERING WITH HUMAN SPERMATOGENESIS}

The number of human genes with mutations causing impairment of spermatogenesis is still small (Table 2). Most of them are involved in the genetic control of male gonad development or some somatic development indicating functional linkage. In the clinic best known are the $\underline{A}$ ndrogen Insensitivity $\underline{S}$ yndromes (AIS: Testicular feminization, Reifenstein, Infertile male syndrome) caused by mutations in the androgen receptor (AR) gene, Idiopathic $\underline{H}$ ypo- and hyper-gonadotropic $\underline{H}$ ypogonadism (IHH) caused by mutations in the genes for the Follicle-Steroid- or Luteinizing hormone receptors (FSHR/LHR), respectively in the KAL-1 gene causing Kallmann syndrome. A polygenic inheritance pattern has been proposed for the Kallmann syndrome, the $\underline{K}$ artagener Syndrome (KS) and Globozoospermia, i.e., caused by mutations in different genes.

Less known in the clinic are mutations in the INSL3 and LGR8-GREAT genes causing cryptorchidism, mutations in the DM-1 gene causing male infertility associated with the autosomal dominant dystrophica Myotonica (DM) syndrome, and the (CAG)-variants of the mitochondrial DNA polymerase (POLG) locus associated with male infertility. The clinical phenotypes of all syndromes associated with male inferility and with a distinct profile of inheritance are described in detail in Victor McKusicks's ,Mendelian Inheritance in Man (MIM)“, respectively online (OMIM), under the given OMIM reference numbers (http://www3. ncbi.nlm.nih.gov/omim/).

\section{ANDROGEN RECEPTOR GENE (AR) LOCUS}

The androgen receptor (AR) gene is a member of the large intracellular family of glucocorticoid receptors which

Table 2. Clinical Syndromes with Male Infertility as Pleiotropic Mutation Effect

\begin{tabular}{|c|c|c|c|c|}
\hline \multirow{2}{*}{ Syndrome } & \multirow{2}{*}{ Chromos. pos. } & \multirow{2}{*}{ Gene-locus } & \multicolumn{2}{|c|}{ OMIM* Reference No. } \\
\hline & & & Disease & Gene \\
\hline Alpha-Thalassemia, Mental Retardation (X-linked) (ATRX) & $\mathrm{Xq13}$ & $\mathrm{XH} 2$ & 301040 & 300032 \\
\hline Bardett-Biedl-syndrome (BBS2) & $16 \mathrm{q} 21$ & BBS2 & 209900 & 606151 \\
\hline $\begin{array}{l}\text { Cystische Fibrosis (CF) } \\
\text { Bil. Aplasia Vas Deferentia (CBAVD) }\end{array}$ & $7 \mathrm{q} 31.2$ & CFTR & $\begin{array}{l}219700 \\
277180\end{array}$ & $\begin{array}{l}602421 \\
602421\end{array}$ \\
\hline Dystrophia Myotonica (DM-1) & $19 \mathrm{q} 13.2-\mathrm{q} 13.3$ & DMPK & 160900 & 605377 \\
\hline Fragile-X (FRAXA) & $\mathrm{Xq} 27.3$ & FMR1 & 309550 & 309550 \\
\hline Gorlin-syndrome (PPS) & $1 \mathrm{q} 32$ & not known & 119500 & not known \\
\hline Kallmann 1 (X-linked) Anosomia & $\mathrm{Xp} 22.3$ & KAL-1 & 308700 & 308700 \\
\hline Kallmann 2 (dominant) & $8 p 11-12$ & FGFR1 & 147950 & 136350 \\
\hline Kallmann 3 (recessive) & not known & not known & 244200 & not known \\
\hline Kartagener-Syndrom & $\begin{array}{c}\text { 5p15-p14 } \\
7 \mathrm{p} 21 \\
9 \mathrm{p} 21-\mathrm{p} 13\end{array}$ & $\begin{array}{c}\text { DNAH5 } \\
\text { DNAH11 } \\
\text { DNAH1 }\end{array}$ & $\begin{array}{l}244400 \\
244400 \\
244400\end{array}$ & $\begin{array}{l}603335 \\
603339 \\
604366\end{array}$ \\
\hline Kennedy-Syndrom (SMAX1) & $\mathrm{Xq} 11-12$ & AR & 313200 & 313700 \\
\hline McKusick-Kaufman (MKKS) & $20 \mathrm{p} 12$ & MKKS & 236700 & 604896 \\
\hline Noonan-syndrome (NS1) & $12 \mathrm{q} 24.1$ & PTPN11 & 163950 & 176876 \\
\hline Prader-Willi-syndrome (PWS) & $15 q 11-13$ & $\begin{array}{l}\text { SNRPN } \\
\text { Necidin }\end{array}$ & $\begin{array}{l}176270 \\
176270\end{array}$ & $\begin{array}{l}182279 \\
602117\end{array}$ \\
\hline Rothmund-Thomson-syndrome (RTS) & $8 \mathrm{q} 24.3$ & RECQL4 & 268400 & 603780 \\
\hline Stein-Leventhal-syndrome (PCO) & $15 q 23-24$ & CYP11A & 184700 & 118485 \\
\hline Werner-syndrome (WRN) & 8p12-p11.2 & RECQL2 & 277700 & 604611 \\
\hline Wilms-Tumor; Denys-Drash-syndrome & $11 \mathrm{p} 13$ & WT1 & 194080 & 194080 \\
\hline
\end{tabular}

*OMIM: Online Mendelian Inheritance in Man (http://www3.ucbi.ulm.nih.gov/Omim) 
are generally kept in an inactive state by inhibitors and in the absence of their ligands. Upon ligand binding, they get activated, move to the nucleus and bind to DNA. For its full activity a strong interaction between the $\mathrm{N}$ and $\mathrm{C}$ terminal peptide domain is essential. Ligands are the hormones testosterone (T) and dihydrotestosterone (DHT) which mediate a wide range of developmental and physiological responses in male sexual differentiation, pubertal maturation and the maintenance of spermatogenesis. They are therefore also called androgens.

Production of testosterone $(\mathrm{T})$ begins at the eighth week of pregnancy in fetal Leydig cells initiating the development of the male gonad from the Wolffian ducts. This includes formation of the epididymis, vas deferens, and seminal vesicles. Formation of the male external genitalia (penis, scrotum) requires the dihydrotestosterone converted from testosterone by the steroid $5 \alpha$-reductase 2 (SRD5A2). The androgen receptor gene is not expressed in germ cells but in Sertoli cells at different phases [128] supporting its role in the coordinate promotion of male specific gonad and germ line development. After ligand binding the protein dimerizes and translocates to the cell nucleus where it binds to specified palindromic DNA elements (5'-TGTTCT-NNNAGAACA-3') defined as ARE (androgen responsive element) sites. Binding to a number of nuclear co-activators [129] the dimerized AR protein promotes the transcription of multiple target genes. The AR interacting proteins are listed in a database (http://ww2.mcgill.ca/androgendb/ARinteract. pdf).

The androgen receptor protein has a long N-terminal peptide domain (555 amino acids) encoded by exon 1 "Fig. (5)". This functions as transactivation domain (TAD) by modulating the transcriptional activity of the AR-dependent downstream genes. Exons 2-3 encode the peptide domain, 556-623, responsible for DNA binding (DBD) and exons 4-8 encode the C-terminal peptide domain, 624-915, responsible for androgen-binding (ABD). In addition to these prinicipal functions all 3 domains embody subsidiary functions that affect dimerisation, nuclear localisation and transcriptional regulation.

The TAD region in exon 1 is variable in length encoding a repetitive tract of glutamines (coded by $\left.\mathrm{CAG}_{n} ; n=9-36\right)$ and of glycins (coded by $\mathrm{GGC}_{\mathrm{n}} ; \mathrm{n}=16-27$ ). This polymorphism regulates quantitatively $\mathrm{AR}$ promoter activity which is enhanced with lower and reduced with higher numbers of the CAG-repeat [130]. Whether lower AR transactivation values would also impair the rate of spermatogenesis is still an open question [131-133]. In a large comparative study including 600 fertile and 674 infertile men from Europe no statistical different numbers of CAG-repeats were found in the fertile and infertile men group [134] and this was confirmed in other studies with 119 infertile men of Caucasoid origin [135] and 280 men from an Indian population [136]. However, probably ethnically differences exists for the functional phenotype of the TAD peptide activating downstream spermatogenesis genes in some other human populations.

It this context it is interesting to note that $\mathrm{CAG}$ repeat length above $\mathrm{N}=38$ are associated with the occurrence of a severe neurodegenerative disease, Spinal Bulbar Muscular atrophy (SBMA: Kennedy syndrome: OMIM-ref: 313200). This syndrome is characterized by progressive degeneration of anterior motor neurons and a late onset of mild androgen resistance (MAIS). The SBMA CAG disease alleles range between $\mathrm{N}=38-62$ [135]. This unusually large extension of

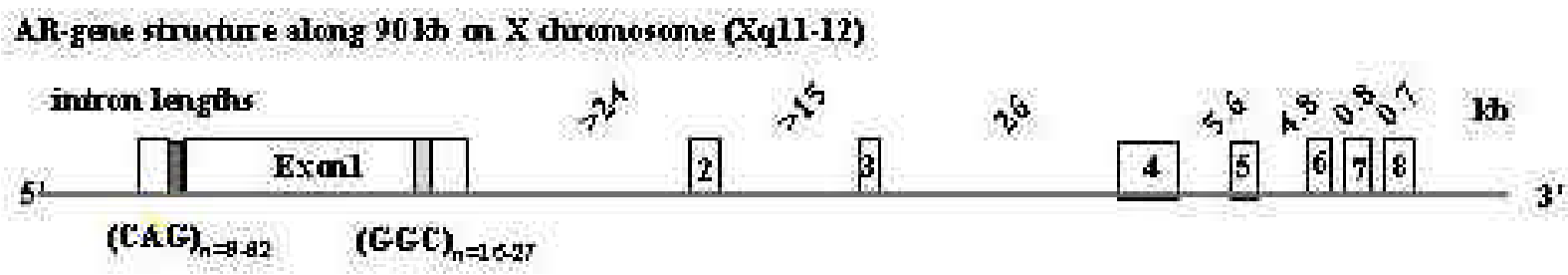

AR-protein (915 a)

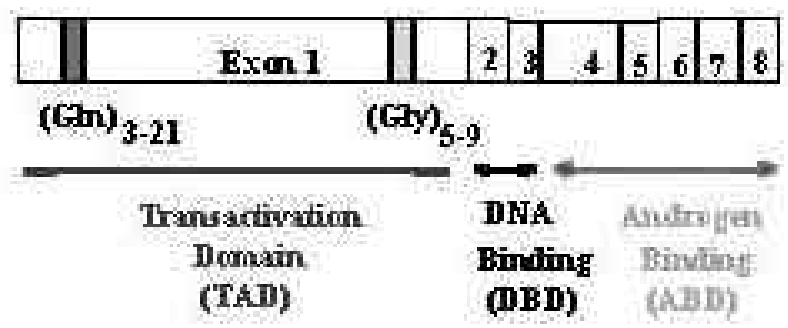

Fig. (5). Schematic view on the exon structure of the human Androgen Receptor (AR) gene with its 3 functional domains. The AR gene is located on the long arm of the $\mathrm{X}$ chromosome (Xq11-12) along $90 \mathrm{~Kb}$. The first exon encodes the transactivation domain (TAD) forming the active gonad-specific transcription factor complex by binding with a series of other transcription factors. It has a polymorphic length due to two repetitive triplets $(\mathrm{CAG})_{\mathrm{n}}$ and $(\mathrm{GGC})_{\mathrm{n}}$ with variable $\mathrm{n}$-values. Above the $\mathrm{n}$ value of 38 for the CAG repeat, the androgen receptor becomes a causative agent for Spinal Bulbar Muscular Atrophy (SBMA) a severe neuro-degenerative disease. The androgens testosterone (T) and dihydrotestosterone (DHT) are the ligands binding to the androgen binding region (ABD) encoded by exon 4-8. Specific point mutations associated with male infertility were found in the TAD and ABD region, respectively. The DNA binding region (DBD) of the AR protein has been mapped to exon 2 and 3. 
the polyglutamine tract in the AR gene is the causative agent for this neurodegenerative disease. Surprisingly, however, despite these large CAG tracts many SBMA patients are not infertile. Therefore, it must be questioned whether a higher number of the CAG-repeat in the TAD domain can cause male infertility like it cause the SBMA syndrome. Nevertheless there is no doubt that androgens contribute to the initiation and maintainance of the formation of spermatozoa. The androgen-receptor gene must therefore be also involved in the regulative genetic network controlling spermatogenesis.

The general high grade of sequence variations in the AR gene (more than 300 point mutations in the AR-database: http://ww2.mcgill.ca/androgendb/AR23C.pdf) reflects a high structural flexibility of the dimeric AR-protein in its functional complex with the multiple co-activators together then resulting in a gonad-specific transcription factor. Consequently, no specific pathology is found for most AR gene mutations but more a variety of pathological phenotypes ranging from testicular feminisation with male infertility (CAIS: complete androgen insensitivity syndrome) to only male infertility with a mild androgen insensitivity (MAIS). This variability is the consequence of the quantitative gradient of the T/DHT binding efficiency in the ABD region of the AR protein "Fig. (5)". Mutation analysis of the AR gene should therefore be offered to all patients where male infertility is associated with a mild androgen resistance syndrome like Rosewater-Syndrome and Reifenstein-Syndrome (OMIM-ref. 312100, 312300).

Most AR gene mutations are missense point mutations. Mutation analysis must therefore be carried out directly by nucleotide sequence analysis. Specific point mutations associated with male infertility were found in the TAD and $\mathrm{ABD}$ region of the $\mathrm{AR}$ gene [138]. A M886V mutation found in 3 patients with severe oligozoospermia and a $\mathrm{N} 727 \mathrm{~K}$ mutation found in one patient both reduced the transactivation activity of the AR protein due to a reduced interaction with the TIF2 co-activator in the ABD region and the TAD region [138]. A clear therapeutic perspective for these patient's infertility is given by administration of the androgen analogue, mesterolone [139].

In cases where an increased length of the CAG repeat in AR exon 1 has been identified in the infertile patient, it is advisable to exclude the risk of transmission of Kennedy syndrome to the patient's daughter before applying IVF/ICSI. For this purpose a DNA sample extracted from the patient's sperms is needed to carry out a CAG-repeat pattern analysis in his germ cells [140]. Although it is expected that the SBMA risk is low when long CAG repeats were not found in the AR gene of his fertile brother or father [140, 141], this risk would become significant when the CAGrepeat number in the patient's sperm DNA would increase beyond the so-called pre-mutation value $(n>33)$ then inducing the SBMA disease in his female IVF/ICSI offspring.

\section{FOLLICLE-STEROID HORMON-/ LUTEINZING HORMON RECEPTOR (FSHR/LHR) LOCUS}

The receptors for the gonadotropins Follicle-steroid hormone (FSH) and Luteinizing hormone (LH) belong to the family of G-proteins coupled receptors. They are characterized by a large extracellular domain that binds specifically the LH or FSH heterodimers. A $\alpha$-helical 7times plasma membrane piercing transmembrane domain links it to the intracellular domain which is coupled to the cellular G-protein signal pathway converting ATP to c-AMP via the adenylcyclase enzyme complex. Upon extracellular ligand binding (FSH or LH) conformational change of the intracellular receptor protein domain leads to the binding of G-proteins [142]. This structural relationship indicates a common origin of both genes (designated as FSHR and LHR) and a functional relationship. This also gained support by their clustered localisation on the short arm of chromosome $2(2 \mathrm{p} 21)$ and their related exon structures. The extracellular domain is encoded by exon 1-9 (FSHR) and exon 1-10 (LHR) respectively. The transmembrane, as well as the intracellular domains, are encoded in both genes by the long last exon (1251 nt in FSHR; $1200 \mathrm{nt}$ in LHR).

Surprisingly, a variable suppression of spermatogenesis and fertility was diagnosed in men homozygous for the inactivating A189V mutation in exon 7 of the FSHR gene [143]. This questioned the essential role of FSH and FSHR expression for the initiation of spermatogenesis in human. Although FSH/FSHR action is required to increase testicular size, spermatogenesis can occur in the presence of severe FSH resistance as long as there is a normal production of testosterone. These observations have been confirmed recently in FSHR and FSH knockout mice [144]. Three single nucleotide polymorphisms (SNP) of the FSHR gene, one in the promoter region and 2 in exon 10 had also no influence on male fertility despite a significant correlation between these polymorphisms and the basal FSH levels have been diagnosed in females [145].

Mutations in the LHR gene leads to hypogonadal phenotypes (Leydig cell hypoplasia, $\mathrm{LCH}$ ) because of a delay in fetal and pubertal male development (male pseudohermaphroditism, MPH). MPH can be caused by different genetic anomalies. Among them are anomalies of the Leydig cell differentiation pathway causing hypoplasia or even absence of the Leydig cell (LCH). A number of mutations in the LHR gene resulting in complete or partial resistance to $\mathrm{LH}$ and associated with variable pathologies of the male gonad have been reported [146]. Male infertility then occurs because of male gonad dysgenesis including micropenis and hypospadias.

Familial male-limited precocious puberty (FMPP) has been diagnosed in patients with a constitutive activation of the LH transduction pathway [146]. It is a dominant disorder which is caused by two LHR mutations (D578G and M571I) located in the $6^{\text {th }}$ transmembrane domain [147]. The most severe phenotype resulting from altered LH-LHR interaction is characterized by an external female phenotype with a blind ending vagina and primary amenorrhoea. In summary, the variance of pathological phenotypes associated with LHR mutations is similar as has been found with mutations in the androgen receptor gene (see above).

Male infertility as the consequence of mutations in the gonadotropins themselves is rare. FSH and LH are heterodimeric molecules that share a common $\alpha$-subunit (also with chorionic gonadotropin, $\mathrm{CG}$ and thyroid-stimulating hormone, TSH) and have specific $\beta$-subunits. The single 
gene encoding the common $\alpha$-subunit has been mapped to chromosome 6 (6q12-21). The FSH- $\beta$ subunit encoding gene has been mapped to chromosome 11 (11p13), the LH- $\beta$ subunit encoding gene to chromosome 19 (19q13.32) where it is linked with six copies of the human CG gene. FSH is essential for Sertoli cell proliferation and maintenance of sperm quality in the testis. The functional action of FSH might be different in the mouse and human germ line since males with FSH- $\beta$ mutations present with azoospermia [148] whereas homozygous FSH- $\beta$ knockout mice had small testes and oligozoospermia but were fertile [4]. Only one LH- $\beta$ gene mutation associated with male infertility has been reported [148].

\section{KALLMANN 1 (KAL-1) GENE LOCUS}

The KAL-1 locus has been mapped to the X chromosome (Xp22.3) [149-151]. KAL-1 expression escapes X inactivation, has a putative non-functional homologue on the Y chromosome "Fig. (1)", and shows an unusual pattern of conservation across species including Caenorhabditis elegans [152]. The predicted protein anosmin-1 plays a key role in the migration of Gonadotropin Releasing Hormone (GnRH) neurons and olfactory nerves to the hypothalamus and has significant similarities with other proteins involved in neural cell adhesion and axonal pathfinding, as well as with protein kinases and phosphatases. This supports that the KAL-1 gene could have a specific role in neuronal migration control [153] and that $\mathrm{GnRH}$ is a key regulator of reproduction and sexual behaviour.

KAL-1 mutations (intragenic deletions and point mutations) $[154,155]$ cause the pathology of Kallmann syndrome typically defined as an association between hypogonadotropic hypogonadism and anosmia, i.e. the inability to smell. Since it occurs more frequently in men $(1: 10000)$ than in women (1:50000) X-linked inheritance has been predicted (KAL-1) although also examples of dominant (KAL-2) and autosomal recessive (KAL-3) inheritance has been described (Table 2). Loss-of-function mutations in the fibroblast growth factor receptor 1 (FGFR1) gene located on the short arm of chromosome 8 (8p11-12) were identified recently as the molecular base of the dominant autosomal KAL-2 locus [156]. Since the KAL-1 and FGFR1 genes were found to be co-expressed at different sites during embryonic development a functional interaction between both proteins can be proposed. This would also explain the higher prevalence of Kallmann syndrome in males.

Genetically, Kallmann syndrome is therefore heterogenous and genotype-phenotype correlations are difficult to settle [157]. There is some evidence that KAL-1 gene deletions in Xp22.3 sometimes include also functional elements of other genes like of DAX-1 located in the neighbourhood of KAL-1. Since DAX-1 mutations cause hypogonadotropic hypogonadism associated with adrenal hypoplasia congenita (AHC) during infancy [158], some patients with Kallmann syndrome and renal agenesis might present with KAL-1 gene mutations influencing the expression of the DAX-1 gene as well [159]. Kallmann syndrome is the most common X-linked disorder with male infertility. The patients can be treated usually successful by a hormone replacement therapy.

\section{MALE INFERTILITY SYNDROMES WITH POLY- GENIC INHERITANCE PATTERN}

The most prominent example where a male infertility syndrome is associated with mutations in different genes is the immotile cilia syndome: primary ciliary dyskinesia (PCD; OMIM no. 242650), also called Kartagener syndrome (KS; OMIM: 244400) when associated with situs inversus [187]. The prevalence of PCD is estimated with 1 in 20.00060.000 but as $\mathrm{KS}$ it appears in a more frequent range between 1 in 8.000-25.000. Spermatozoa of men with the Kartagener syndrome (KS patients) are immobile like the cilia in their respiratory tract. Complete absence of dynein arms forming temporary cross brigdes between adjacent ciliary filaments could be demonstrated as causative agent. Dynein arms are believed to be responsible for generating movement in cilia and sperm tails. But the ultrastructural defects observed in KS patients are variable [161] and patients with the phenotype of Kartagener syndrome in somatic cells but no effects on sperm motility are also observed [162]. Although pedigree analysis mostly suggests an autosomal recessive inheritance pattern of KS, X-linked and autosomal dominant inheritance patterns are reported as well [163]. This points to genetic heterogeneity of the Kartagener syndrome, i.e., caused by mutations in multiple genes although of the same genetic network. A genome-wide linkage analysis has now confirmed the expected extensive locus heterogeneity for the PCD syndrome [164] and the first three genes causing Kartagener syndrome if mutated have been molecularly isolated: the gene encoding the dynein axonemal intermediate chain 1 (DNAH1) on the short arm of chromosome 9 (9p13-21) [165], the gene encoding the dynein axonemal heavy chain 5 (DNAH5) on the short arm of chromosome 5 [166], and the gene encoding dynein axonemal heavy chain 11 (DNAH11) on the short of chromosome 7 (7p21) [167]. The axoneme is composed of about 250 distinct proteins [168]. Therefore it can be expected that also mutations in the other dynein axonemal arm genes will cause a KS phenoytpe.

A polygenic inheritance patterns has been also discussed for the phenotype of round headed spermatozoa induced by malformations of the acrosome [169]. The number of roundheaded sperms can vary between 14 and $71 \%$. Two types of globozoospermia are distinguished: Type I is characterised by a complete lack of acrosome and acrosomal enzymes and by a spherical arrangement of the chromatin. These sperms are unable to penetrate the zona pellucida, causing infertility. Type II has some acrosomal activity covering a canonical nucleus surrounded by large cytoplasmic droplets [170]. Elevated chromosome aneuplodies were found in roundheaded sperms with FISH using probes for chromosomes 13, $15,18,21, \mathrm{X}$, and $\mathrm{Y}[171,172]$, although this could not be confirmed by other authors $[173,174]$. However, in all cases an increased damage of the sperm chromatin structure has been reported, indicating a high mutational load in the paternal DNA structure of these patients. Globozoospermic sperms will therefore have an inherent low fertilisation rate also with the ICSI protocol, because an increased damage of sperm chromatin and DNA is generally decreasing the sperms fertilisation capacity and also impair early embryonic development [175]. 


\section{INSL3 AND LGR8-GREAT GENE LOCI}

INSL3/LGR8-GREAT are both functional involved in the molecular mechanism of testis descent. Testicular descent from abdomen to scrotum occurs in two distinct phases: the trans-abdominal phase and the inguino-scrotal phase. The gubernaculum connects the gonad to the inguinoscrotal region and is involved in testis descent. It rapidly develops in the male fetus, whereas development in the female fetus is lacking. Since absence of Insl3 in male mice resulted in bilateral impairment of testis descent, i.e., cryptorchidism [176, 177] it has been proposed that mutations involving this gene may be a cause of cryptorchidism also in men. Cryptorchidism is one of the most frequent congenital abnormalities in humans, involving $2 \%$ of male births (OMIM ref.: 219050). Cryptorchidism can result in infertility and an increased risk for development of germ-cell tumours. The aetiology of cryptorchidism is for the most part unknown and appears to be also genetically heterogeneous. Other factors involved in gubernaculum development are e.g. androgens and anti-Mullerian hormone (AMH).

In human, INSL3 has been mapped on chromosome 19 (19 p13.2). It is also known as relaxin-like factor (RLF) and Leydig insulin-like protein (LEY I-L) and a member of the insulin/relaxin hormone superfamily that is highly expressed in Leydig cells. The frequency of INSL3/RLF gene mutations as a cause of cryptorchidism seem however to be low, because only 2 of $145(1.4 \%)$ formerly cryptorchid patients were found to have a INSL3 mutation [178]. Mutation analysis of the coding regions of the INSL3 gene was performed in 145 formerly cryptorchid patients and 36 adult male controls using single-strand conformational polymorphism (SSCP) analysis. Two mutations, R49X and P69L, and several polymorphisms were identified.

INSL3 is the ligand for LGR8, one of the recently identified $G$ protein-coupled orphan receptors (LGR4-8) homologous to gonadotropin and thyrotropin receptors [179]. Transgenic mice missing the LGR8 gene also displayed cryptorchidism. The same mouse gene but designated as GREAT (G-protein-coupled REceptor Affecting Testis descent) because identified by a different research group [180] was screened for some nucleotide variants in 61 cryptorchid human patients Comapred with theGREAT cDNA sequence a unique missense mutation (T222P) was identified in the ectodomain of the GREAT receptor [180]. Two sequence variants in exon $12(\mathrm{~A} / \mathrm{G}$ transversions at nucleotide positions 957 and 993) were identified in 40 out of the 61 cryptorchid patients but also in the normal control men displaying 3 different haplotypes (A957 and A993, A957 and G993, G957 and G993).

The low frequency of mutations found in the INSL3 and GREAT/LGR8 gene locus of patients with maldescent testes suggest that this frequent pathology must be caused also by mutations in some other genes. Indeed, some candidate genes were already indicated by chromosome analyses to be probably located on chromosome $1,2,8,9,22, \mathrm{X}$ and the $\mathrm{Y}$ chromosome [181].

\section{DYSTROPHICA MYOTONICA (DM) LOCUS}

Myotonic muscle dystrophy (DM) is a dominant inherited disorder in which the muscles contract but have decreasing power to relax. The major gene (DM-1 or DMPK) causing about $95 \%$ of the DM disease has been mapped on chromosome 19 (19q13.2-3). Since the Nterminal domain is highly homologous to cAMP-dependent serine-threonine protein kinases, myotonin-1 has been recognised as a phosphorylation enzyme (called DMPK). Myotonic dystrophy is caused by mutations producing pathogenic RNA molecules that accumulate in nuclear foci because of an increased amplification of a CTG- repeat located in the 3 UTR of exon 15. Unaffected individuals have between 5 and 35 copies of the CTG-triplet, myotonic dystrophy patients who are minimally affected have at least 50 repeats, while more severely affected patients have an expansion of up to several thousand repeats. An unusual feature of this illness is that its symptoms usually become more severe with each successive generation (anticipation).

This disorder commonly occurs during young adulthood although it can occur at any age and is extremely variable in degree of severity. It can cause mental deficiency, hair loss, cataracts and infertility [182]. Patients with infertility and hypogonadism usually feature only mild somatic defects, although intellectual abilities are often in the low range. Similar to Kennedy disease, clinically relevant gonadal pathologies develops after puberty. Infertile DM patients present with testicular atrophy, loss of libido and of potency [183]. Comparing sperms' capacitation and acrosome reactions in the ejaculates of infertile DM patients and healthy men by different diagnostic tools (like the Pisum sativum and D-mannose receptor expression assays), a complete lack of capacitation and acrosome reaction of sperms from the DM patients has been diagnosed [184]. These anomalies therefore most likely cause the infertility of DM patients. Obviously, ICSI is a therapeutic option for the infertility of DM patients because capacitation difficulties can be easily circumvented by this ART method. However, considering the dynamic expansion of the CTG-repeat in exon 15 of the DM-1 gene from one generation to the next, it is expected that the severity of the DM disease will be increased in the ICSI offspring. DM patients with male infertility asking for IVF/ICSI should therefore visit first a genetic counselling service who can evaluate the severity of the somatic DM risk factor based on the family pedigree.

\section{DNA POLYMERASE G (POLG) LOCUS AND MITOCHONDRIAL DNA}

The human POLG gene locus encoding the catalytic subunit of mitochondrial DNA polymerase has been mapped to the long arm of chromosome 15 (15q25) [185]. POLG is the only DNA polymerase responsible for mitochondrial DNA replication. The protein contains a polyglutamine tract encoded by a CAG repeat in the first POLG exon. This CAG repeat is polymorphic in length as found for the AR gene but with a much lower variability. In different ethnic populations the common ten-repeat allele is found with a uniformly high frequency (0.88) and absent in only $1 \%$ of the individuals [186]. This indicates in contrast to the AR-CAG repeat a strong positive selection for one major $\mathrm{CAG}_{10}$-allele.

In infertile men with moderate oligozoospermia a mutant genotype (absence of the common $C A G_{10}$-allele; designated furtheron as "abs 10" POLG-allele) has now been found at an 
elevated frequency in all populations studied [187]. Using sperm DNA from persons in whom azoospermia was excluded, 9 of 99 infertile males $(9 \%)$ from Finland or England were found to be homozygous for the "abs 10" POLG-allele. In contrast, this allele was present in sperm DNA from all 98 fertile males studied, as well as in all but 6 of 522 healthy controls, whose blood DNA was analysed in parallel. Based on standard Hardy-Weinberg predictions, the homozygous mutant genotype "abs10/abs 10" should be found in approximately $1.7 \%$ of individuals, as was confirmed by Rovio and coworkers [187]. The frequent finding of the "abs10/abs10" genotype in infertile men $(9.1 \%)$ is therefore highly significant. The POLG genotype in blood and sperm was similar in these individuals, thus excluding any effect of de novo tissue-specific mutations. A higher frequency of heterozygosity for the " $a b s 10$ " allele in infertile males $(35 \%)$ than in fertile males $(18 \%)$ or in the general population $(23 \%)$ also suggests a causative influence of this POLG allele on the men's fertility [187]. Given the many rounds of cell division during spermatogenesis and the functional necessity of mitochondrial (mt)DNA for sperm function, it seems plausible that a suboptimal mitochondrial DNA polymerase could result in the accumulation of mtDNA mutations and in failure to complete differentiation. Thus the "abs10" POLG allele would be somehow deleterious to sperm differentiation but would have no obvious, phenotypic effects in other tissues.

The "abs10/abs 10" POLG variant was found at an elevated frequency in men with moderate oligozoospermia in all populations studied. Their sperm quality was below the commonly accepted thresholds for at least 2 out of the 3 common parameters: sperm number $(<20$ million per $\mathrm{ml})$, motility $(<50 \%$ motile $)$ or morphology $(<10 \%$ normal morphology). The finding of a distinct POLG variant in men with moderate oligozoospermia indicates that, at least within European populations, the occurrence of this POLG variant contributes to about $5-10 \%$ of the cases with idiopathic male infertility.

It might be possible that the specific mtDNA replication function of POLG is probably also involved in the deleterious dynamic of the sperm mtDNA sequence. Sperm motility and other parameters of sperm quality appear to be generally correlated with the intactness of the mitochondrial DNA sequence (mtDNA) since in infertile males mtDNA deletions have been found at a larger scale [188-191]. Recently, also an association between asthenozoospermia and a distinct mtDNA haplogroup $\mathrm{T}$ with some point mutations in mitochondrial t-RNAs was reported [192]. Asthenozoospermia contributes to male infertility in about $30 \%$ of all cases. All genes encoding components of the mtDNA maintenance machinery might therefore be regarded as candidates for being involved in male fertility. The motility of spermatozoa is also heavily dependent on the mitchondrial respiratory energy. An impaired energy metabolism of sperms has therefore long been hypothesized to contribute to infertility as well [193].

To summarize, given the high number of putative human male fertility genes, mutations causing male infertility are easily identified if (1) the frequency of the mutation is high, as shown above for the AZFa-c and DAZ1/DAZ2 microdeletions and for the CFTR point mutations, respectively, or, if (2) it is possible to select a distinct patient subgroup out of the large and heterogenous idiopathic male infertility group by e.g. a specific clinical pathology like androgen insensitivity and cryptorchidism, or by a specific hormone profile or semen pathology as found with the Kallmann and Dystrophica myotonica syndromes.

A comprehensive mutation analysis of a given human male fertility gene will be technically always timeconsuming, unless one develops technologies based on chips with high-density oligonucleotide arrays of the gene in question. Another molecular approach with the advantage of studying multiple fertility genes in parallel would be a comparative analysis of the genes' testicular expression profiles on appropiate chip matrices. These studies might be Comparison of RNA chip expression profiles from patients with spermatogenic disruptions at different phases would be then the first step towards a molecular insight in the genetic network controlling human spermatogenesis.

\section{MALE INFERTILITY AS A PLEIOTROPIC MUTA- TION EFFECT OF SOMATIC DISEASES}

Multiple somatic genetic disorders cause male infertility pleiotropically (Table 2). That means that patients with mutations in e.g. the DM-1 gene causing myotonic dystrophy are not always infertile (see above). Considering different cell systems, the primary effect of a gene mutation is not always identical and only sometimes but not always (i.e. pleiotropically) a second pathology occurs in an apparantly remote cell system. This is because of the individual pattern of heterozygous mutations in the other genes which are not visible because of the lack of distinct phenotypes but which share the same genetic control circuit. This individual specific "heterozygosity" is also called "genetic load factor". It also explains why an observed mutant phenotype does not always follow the normal Mendelian rules [194, 195]. According to these rules, recessive and dominant mutations can usually be distinguished in the pedigree by the frequency of the observed pathologies. For pleiotropic gene mutations this is often doubtful as a recessive somatic gene defect linked to male infertility can have a dominant inheritance pattern in the germ line like shown for the CF/CBAVD locus (see above). It is therefore also not surprising when the same mutation in a given gene locus (e.g. AR, CFTR, FSHR) cause a variable pathology or sometimes only display male infertility as a single pathology.

\section{HUMAN SPERMATOGENESIS PHASE MARKER GENES}

If one wants to identify some patient subgroups with disruptions at specific phases of spermatogenesis, a detailed and comparative registration of all molecular clinical data in a personal patient database is an essential prerequiste. In the past this usually includes, besides a detailed description of the patients' hormone profiles and semen parameters, also a detailed histological description of the observed testicular damage. Now, it is possible to improve these classification criteria significantly by the analyses of the testicular expression profiles of some spermatogenic key genes, i.e., of genes which are known from basic research to control 
spermatogenesis at different phases [196]. Such "spermatogenesis phase marker genes" are e.g. DAZL1 for diagnosing the presence of premeiotic germ cells [197], CREM for diagnosing the expression of postmeiotic spermatids [198] and CDY1 for diagnosing the putative presence of mature spermatozoa in the patient's testis tissue [199]. Although formal proof is still missing that these genes are functional required in human spermatogenesis (no gene mutations associated with male infertility are known), the transcriptional and translational activities of these key genes are also most valuable for an evaluation of the residual functional capacity in the patient's germ line. With these data in the clinical patient data base, it is then also possible to predict much better the presence of some mature spermatozoa in the patient testis tubules; This is of upmost clinical importance for all cases of male infertility where a successful testicular sperm extraction (TESE) is needed as a prerequiste for successful ICSI treatments. The expression pattern of some hormone levels, FSH, LH, Prolactin, Testosterone, and also inhibin $\mathrm{B}$, in the infertile men are not predictive for these practical aspects $[200,201]$.

\section{DAZL1 Expression is Diagnostic for the Presence of Germ Cells}

A master control gene for premeiotic germ cell development is the DAZL1 gene encoding a male and female germ line specific RNA-binding protein [202]. It is with the BOULE gene a member of the Y chromosomal DAZ gene family in the AZFc locus (Table 1A). Howver, in contrast to DAZ, the BOULE and DAZL1 genes are found highly conserved with homologues in vertebrates (mouse: boule and Dazl1; Xenopus: Xdazl; zebrafish: zdazl) and invertebrates (Drosophila: boule, Caenorhabitis elegans: cdazl) [203]. The boule gene is found in flies and human. It can therefore be designated as the ancestor of the DAZ gene family which then amplified first from boule to Dazl in vertebrates, then from Dazl to DAZ in primates. This genomic amplification process has been probably triggered by a functional essential extension or an increased requirement for the function of these testicular RNA binding proteins in the different species classes [203, 204].

The presence of DAZL1 transcripts and proteins is diagnostic for the presence of germ cells in the patients' testicular tissue samples. It is therefore not surprising that any impairment of the spermatogenic process can be visualised by a moderate till severe reduction of DAZL1 gene products [197]. Since DAZL1 mRNAs have been also found in the semen fluid [205] a quantitative RT-PCR analyses of DAZL1 gene expression is possible without any invasive clinical treatments and can be included in the normal andrological semen quality workup. Using polyclonal antisera raised against a specific DAZL1 peptide it has been shown that DAZL1 proteins are accumulating in the midpiece of mature spermatozoa [205]. Absence of DAZL1 gene products are therefore also indicative for the absence of spermatozoa in the patient's testicular tissue. Since also DAZ proteins have been found to accumulate in late spermatids and human sperm tails "Fig. (6)" [206] it can be assumed that the functional activities of the multiple DAZ genes in human spermatogenesis significantly exceeds beyond the function of the single DAZL1 gene in mouse spermatogenesis.

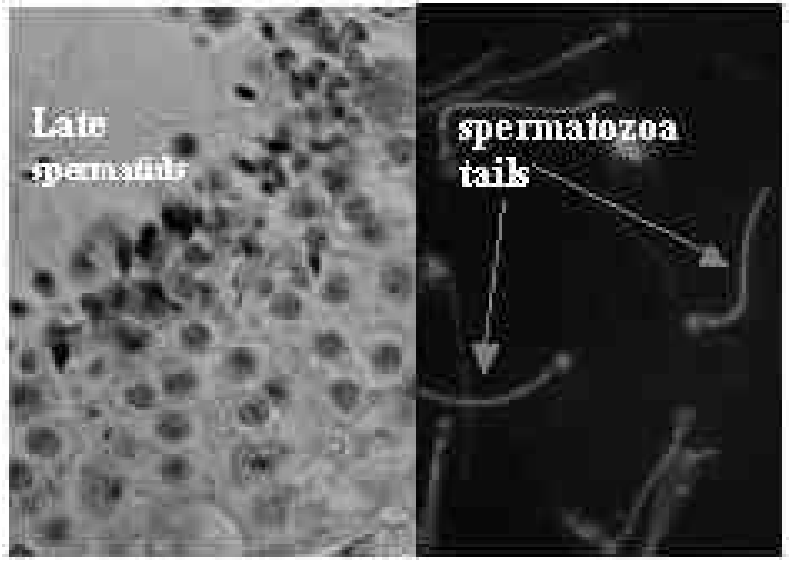

Localisation of DATr proteins

Fig. (6). Immunostaining with DAZ2-antiserum on human testis tissue sections (left) and immunofluorescence with DAZ2antiserum on human spermatozoa (right) strongly indicates the presence of DAZ2 proteins in late spermatids and in sperm tails (see arrows).

\section{CREM Expression is Diagnostic for the Presence of Postmeiotic Germ Cells}

The CREB/CREM transcription factors are expressed in germ cells and Sertoli cells in a circidian fashion dependent on cAMP signaling induced by the pituitary gonadotropic hormones FSH and LH [207]. By alternative promoter usage and alternative exon splicing events different CREB/CREM protein products are translated which function as transcriptional activator or repressor for distinct target genes. CREB is poorly expressed in testis. CREM is expressed at very high levels and therefore thought to be a master regulator of the male germ cell along its whole pathway. Most of the CREM target genes still need to be identified (see e.g.: http://www.dkfz-heidelberg.de/tbi/crem/). They are recognised by the presence of a c-AMP-responsive element (CRE) in their promoter regions generally serving as binding site for the CREB/CREM transcription factors. Promiment examples are the genes encoding transition protein-1 (Tp-1), protamine-1 (Prm-1) and protamine-2 (Prm-2) which are specific structural components of the postmeiotically maturating sperms.

In human, the CREM gene has been mapped to the short arm of chromosome 10 (10p12.1-p11.2) [208]. It spans about $85 \mathrm{~kb}$ of genomic DNA and contains 14 exons encoding different functional domains "Fig. (7A)". These are spliced together in a variable fashion after transcription from four different promoter sites (P1-P4) creating multiple mRNA lengths. Additionally FSH appears to regulate CREM expression by alternative polyadenylation resulting in a dramatic enhancement of CREM transcripts stabilities [209]. Transcripts starting from $\mathrm{P} 1$ and including the Q-rich transactivation domains exon $\mathrm{C}(\tau 1)$ and/or $\mathrm{G}(\tau 2)$ encode CREM activator proteins for the postmeiotic germ cell 
transcription [209]. CREM $\tau$ mRNA expression in the cytoplasm of round spermatids therefore indicates postmeiotic germ cell differentiation. Expression of only the CREM repressor isoforms, $\alpha, \beta, \gamma$ in pachytene spermatocytes is indicative for a meiotic arrest of the patient's spermatogenesis [210].

Other testis-specific CREM isoforms with activating functions are those which include the $\theta 1$ and $\theta 2$ exons "Fig. (7A)". These CREM transcripts are starting from the P3 and P4 promoter [211]. Transcription from the c-AMP-inducible intronic P2 promoter gives rise to the ICER (Inducible-cAMP-Early-Repressor) products, which are truncated CREM proteins containing only their C-terminal Basic Region (BR) and the two DNA-binding Domains (DBD I and II). ICER proteins binds to $\mathrm{CRE}$ elements and therefore are able to repress the activity of the own $\mathrm{P} 2$ promoter constituting a negative autoregulatory loop [212]. Most interesting, the testis-specific CREM activating function is not controlled by a protein kinase mediated phosphorylation step but through the physical and functional association between the activation domain of CREM and ACT (activator of CREM in testis), a LIM-only protein with coactivator properties expressed only in testis tissue [213].

Diagnostic for the presence of postmeiotic germ cells in the patient's testis tissue would be a comparative expression analysis of the activating CREM isoforms $\theta 1, \theta 2$ and $\tau$ mRNAs in the testicular tissue of men with normal spermatogenesis and of men with undefined spermatogenic arrest. RT-PCR experiments diagnostic for the presence of CREM $\tau 1$ mRNA with primer pairs spanning exon $\mathrm{C}$ encoding the $\tau 1$ activation domain "Fig. (7A)", have been performed by Peri and coworkers. CREM $\tau 1$ mRNA transcripts were indeed only identified when postmeiotic germ cells have been found in the patient's ejaculate [210]. A parallel analysis of the premeiotic CREM repressor transcripts $\alpha, \beta$, and $\gamma$ served as the internal control. Similar diagnostic RT-PCR experiments have been also performed for the identification of the other exons encoding the activating domains $\tau 2$ (exon $G$ ) and exon $\theta 1$ or $\theta 2$, respectively [198, 211]. Two CREM activator transcripts including the $\tau 2$ domain with and without the $\gamma$ exon "Fig. (7A)" have been identified in testis tissue RNA samples, but surprisingly not any CREM transcripts including exon $\mathrm{C}$ with the $\tau 1$ domain as was found by Peri et al. [210] have been registered [198].

With annother set of exon probes multiple testis RT-PCR products prepared with primers specific for exon $\theta 1, \theta 2$ and the antisense primer from the 3'UTR in exon $\mathrm{Ib}$, were identified "Fig. (7B)". They include exon $\theta 1$ or $\theta 2$ respectively, E, F, G, H, and Ib but lack exon C and exon Ia. RT-PCR-experiments diagnostic for the presence of postmeiotic germ cells in testicular tissue or semen fluid should therefore focus on the identification of CREM $\tau 2$ and $\theta 1$ or $\theta 2$ transcripts because these seem to be more prominent than CREM $\tau 1$ transcripts. If this simple diagnostic CREM RT-PCR-assay would work also routinely on RNA samples from semen fluid, it would be extremely valuable in all cases of idiopathic male infertility were the tissue sample is too small for a parallel CREM $\tau$ mRNA analysis and where multiple TESE are needed for the isolation of single sperms.
This CREM RT-PCR analysis can be corroborated with a CREM protein analysis in the patients' testicular tissue sections. The CREM protein is only present in the spermatids if the patient's spermatogenesis proceeds through the round spermatid phase [214, 198]. Further analysis for the expression of CREM downstream genes like the TP-1, PRM-1 and PRM-2 genes would be able to pinpoint the postmeiotic arrest phase of the patient's spermatogenesis then in detail [215].

\section{CDY1 Expression is Diagnostic for the Presence of Mature Sperms}

Besides the expression of the protamine-2 gene [216] also expression of the CDY1 gene [199] is a useful molecular marker to predict the presence of testicular sperm in patients with nonobstructive azoospermia. The CDY1 gene locus was mapped in the AZFc deletion interval of the human $\mathrm{Y}$ chromosome (Table $\mathbf{1 A}$ ). It is a member of the CDY gene family with more copies in and proximal to the AZFb deletion interval (CDY2) [69] and on chromosome 6 (CDYL) [85]. CDY1 and CDY2 are retrotransposed mRNAs from the CDYL gene evolved during primate evolution. Only the CDY1 gene have evolved then furtheron a two exon gene structure from which 4 alternative spliced transcripts encoding 3 different protein isoforms have been already documented "Fig. (8)". Only the major CDY1 transcript is identical in sequence to the CDY2 transcript [85]. CDY2 and all CDY1 isoforms are nuclear proteins with a $\mathrm{N}$-terminal chromo-domain recently identified as histone acetyltransferases with a strong preference for histone $\mathrm{H} 4$ [217]. The proteins have been localised in the nuclei of maturing spermatids. At this spermatogenic phase, H4 hyperacetylation takes place during the histone-to-protamine transition of the postmeiotic chromatin condensation process in the rat male germ line [218]. Histone hyperacetylation results in a more open chromatin structure which facilitates not only the spermatogenic histone replacement but also provides an easier access of transcriptionally regulatory proteins like the CREM transcription factors to the postmeiotic sperm DNA. With the use of specific primer pairs for transcripts of the CDY1 and CDY2 genes it has been shown that the spliced minor CDY1 mRNAs "Fig. (8)" are both diagnostic for the presence of mature germ cells [199]. Expression analysis of the CDY1 minor transcripts in testicular tissue or semen fluid is therefore useful to identify the completeness of the patients'spermatogenesis.

\section{AZF-DNA Deletions are Diagnostic for the Absence and Presence of Mature Sperms}

A molecular analysis for AZF DNA deletions in the Y chromosome of azoospermic men is an attractive prognostic tool for the finding of mature sperms in the patient's testis tissue without the need of testicular gene expression analyses. Since it has been shown that patients with a complete $\mathrm{AZFa}$ or $\mathrm{AZFb}$ deletion usually suffer from a complete absence of germ cells (AZFa) or a complete absence of postmeiotic germ cells (AZFb), clinical testicular sperm extractions (TESE) for ICSI treatment are not recommended for these patient groups, because these are usually not successful [61, 219]. However, if a partial or complete AZFc deletion has been diagnosed in the patient's 
A. Human CREM locus alang $85 \mathrm{~h}$ an chromosome 10 (OOp12.1-11.2)

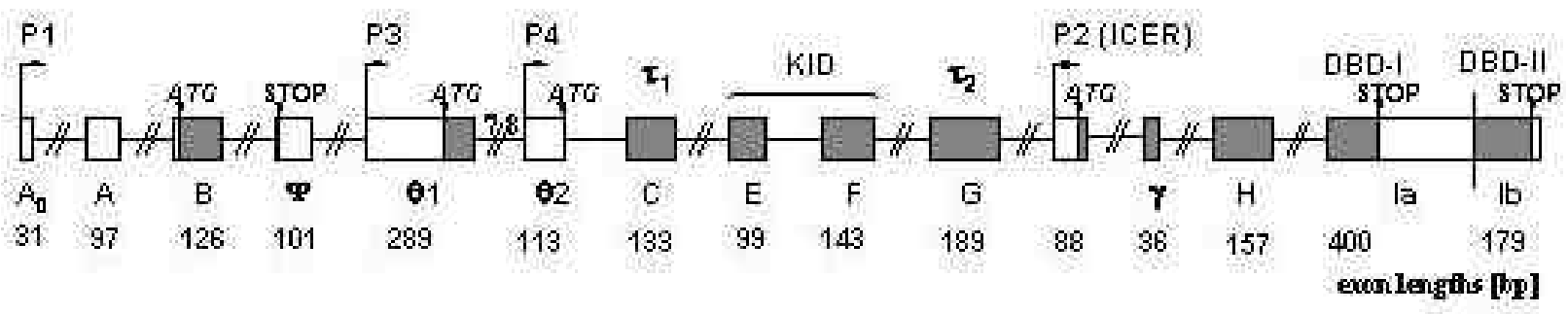

B. RT-PCR fOI CREM splicing variants In human tertis

RT-PCR CREM EXON OI - 3'UTR
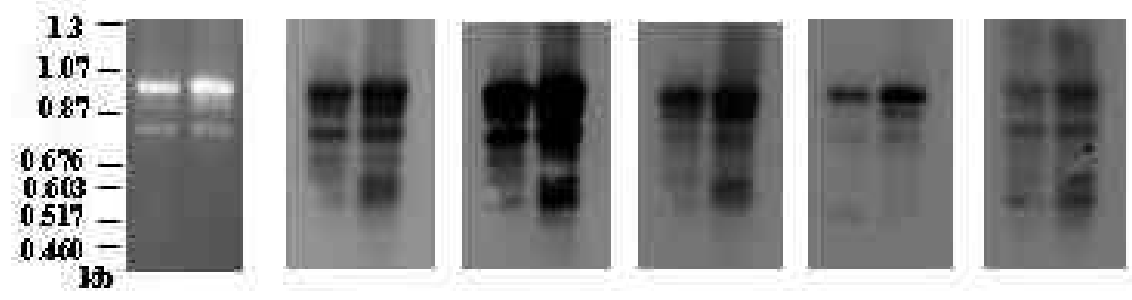

RT-PCR CREM exon $\theta 2$ - 3'UTR
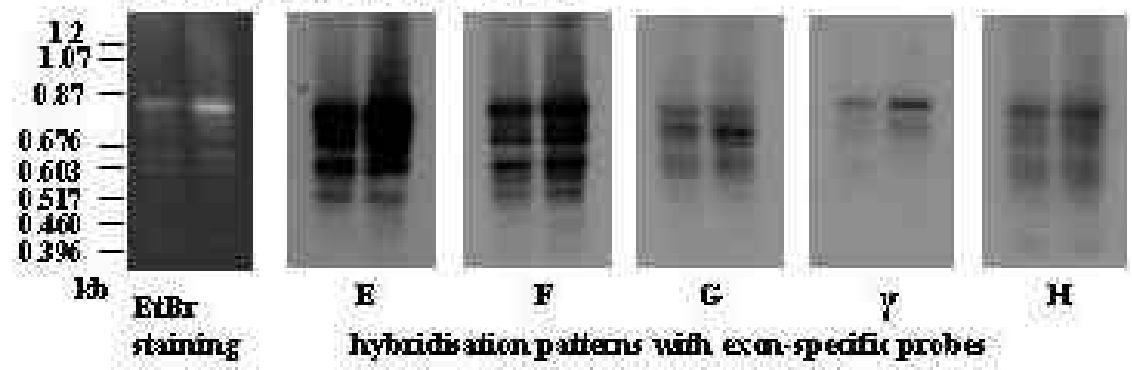

hybridisation pattens uïh exan-specific probes

Fig. (7). A. Schematic view on exon structure of the human CREM locus according to Gellersen et. al. [2002]. The exact lengths for the $\theta 1$, $\theta 2$ and $\tau 1$ exons are given only preliminary. Since CREM transcripts are found to be promoted from four different promoter sites (P1, P2, P3, P4), different CREM proteins are expected. The variability of their encoding open reading frames (ORFs) are indicated by the shadowed exon regions starting at four different initiation sites marked with an ATG and ending at three different STOP sites. CREM transcripts starting from P1, P3, P4 include the Q-rich transactivation domains in exon C and G, respectively, exon $\theta 1$ and $\theta 2$. The $\mathrm{P} 2$ promoter contains an c-AMP inducible CRE element. Therefore CREM proteins of transcripts starting from P2 and only encoding the DNA binding regions DBD-I and DBD-II are functioning as repressors (ICER proteins) for the same promoter site constituting a negative autoregulatory loop. B. Expression of CREM splicing variants containing exon $\theta 1$ and $\theta 2$ in 2 different human testis RNA samples. Prominent CREM RNA variants are already visible after Ethidium-bromide (EtBr) staining of the RT-PCR products in the agarose gels (on the left). More variants are visible after hybridising corresponding blots with specific exon probes as indicated. Marker lengths are given at the left. For further discussion of these results see text.

Y-DNA, testicular mature sperms are often found in single testis tubules because a residual local complete spermatogenesis is typical for this large patient group including the frequent presence of single sperms already in the patient's ejaculate (cryptozoospermia). Important is however to stress, that only complete $\mathrm{AZFa}$ and $\mathrm{AZFb}$ deletions will have this predictive power. Therefore, if deletions have been identified in AZFa or AZFb, they must be also analysed for their molecular extensions as described in the literature [56, 69, 220, 221].

\section{MALE FERTILITY MARKER GENES}

Mature mammalian spermatozoa require a post-testicular maturation process, including their exposure to the specific microenvironment provided by the epididymis. Therefore ICSI fertilisation rates with testis extracted spermatozoa (TESE) are usually lower then with mature spermatozoa isolated from the patient's ejaculates [222, but see also 223]. Also a reduced implantation rate has been reported for ICSI cycles with testicular sperms compared with those using ejaculated sperms [224, 225]. Thus, there is ample circumstantial evidence that the epididymis function is essential for male fertility and that epididymal proteins are involved in this process [226]. However, our understanding of how the individual proteins implement the acquisition of sperm fertilizing ability is still fragmentary. In order to better appreciate the role of the epididymis at a molecular level, a careful analysis of its specific pattern of gene expression needs to be elaborated [227]. In any case, a diagnosis of the 


\section{CDYI gene in AYF c viith altenative spliced transcipts encoding protein isofouns}

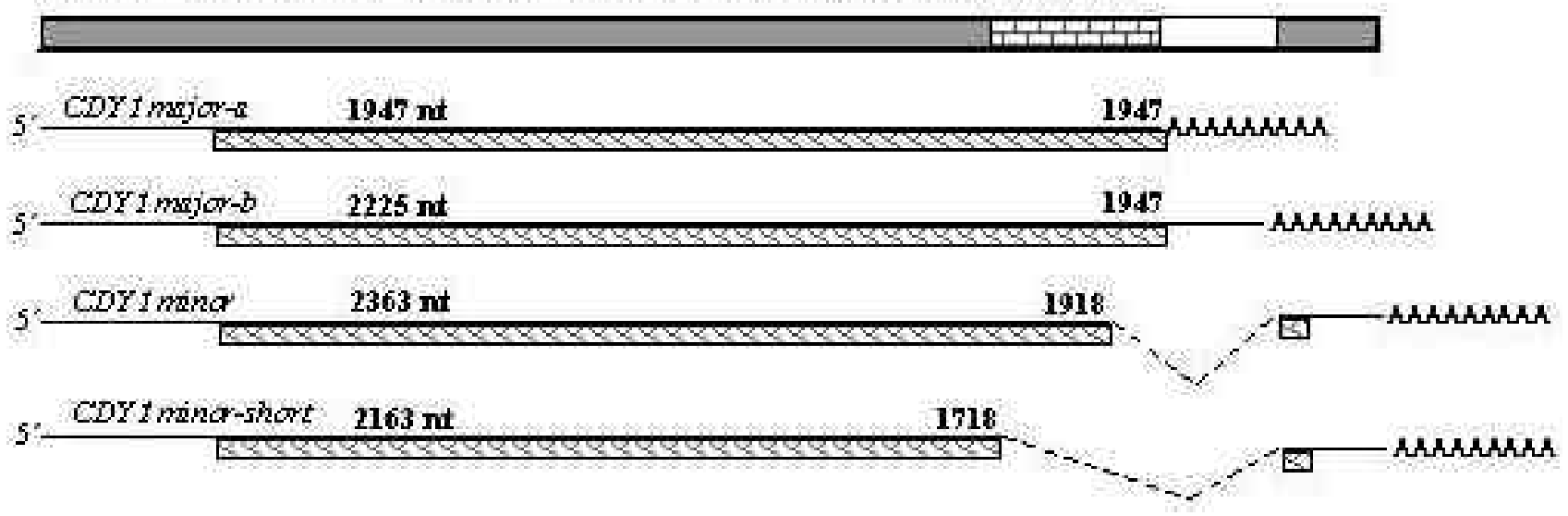

Fig. (8). Schematic view on CDY1 locus in AZFc. The transcription of this CDY gene copy in human testis produces at least four alternative spliced mRNAs published with the following GenBank accession numbers: CDY1 major-a (AF080597), CDY1 major-b (BC033041), CDY1 minor (NM004680) and CDY1 minor-short (this variant was identified by Kleiman et al. 2001 and is not deposited in the GenBank). Both minor variants spliced out an intron sequence from the CDY1 exon at two different 5' splicing sites but with identical 3'splicing sites. This results in an alternative two-exon structure of the CDY1 gene and the translation of 3 protein isoforms. Their variable coding frames are marked with $5 \mathrm{Q}$ below the different transcript lengths given in numbers of nucleotides without the poly(A) tail. The variable 5' intron part is marked with

fertility potential of a semen sample is essential and beyond the analysis of spermatogenesis phase marker genes. Accurate molecular genetic diagnostic tests to determine the sperm's fertility potential are therefore strongly recommended.

\section{PHGPx Expression as Male Fertility Marker}

A prominent male fertility marker protein already expressed in spermatids and then located as major structural protein in the midpiece of sperm tails is the mitochondrial capsule selenoprotein (MCS) encoded by an isoform of the Gluthathion peroxidase gene GPX-4 [228], which is located on the short arm of chromosome 19 (19p13.3) [229]. The GPX-4 isoform encodes the phospholipid hydroperoxide glutathione peroxidase (PHGPx) enzyme expressed in three different forms using alternative start codons. These target the enzyme to the cytosol, mitochondria, or to the nucleus, respectively. Preferential PHGPx gene transcription is observed in the late round spermatids, but ceases then abruptly upon transition to elongated spermatids. The change in shape from round spermatids to the elongated forms timely parallels the change of the chromosomal packaging proteins from histones to protamines. PHGPx activity in spermatids may therefore also functionally contribute to crosslinking of the protamine thiols which is essential for stabilisation of the postmeiotic condensation of sperm chromatin.

In mature spermatozoa PHGPx activity is hardly detectable because it has been transformed to the oxidatively inactivated MCS protein [228]. This switch in the redox status during late sperm maturation is explained by a disappearance of GSH, the usual PHGPx reductant. PHGPx, thus deprived of its usual GSH reduction, becomes crosslinked with itself and with other SH-proteins via selenodisulfide bridges. In the midpiece of mature spermatozoa, the oxidised PHGPx protein represents at least 50 percent of the capsule material that embeds the helix of mitochondria. The mechanical instability of the mitochondrial midpiece that is observed after selenium deficiency also points to an essential role of PHGPx as a structural sperm tail protein.

The PHGPx protein content in sperms can be estimated after reductive solubilization by measuring the rescued PHGPx activity [230]. It was found that the rescued PHGPx activity in infertile men ranged significantly below that of controls $(93.2 \pm 60.1$ units/mg sperm protein vs. $187.5 \pm 55.3$ units $/ \mathrm{mg}$ ). It was particularly low in oligoasthenozoospermic specimens $(61.93 \pm 45.42$ units/mg; $P<0.001)$ compared with controls and asthenozoospermic samples. In isolated motile samples, motility decreased faster with decreasing PHGPx content. Obviously, irrespective of the cause of alteration, the content of PHGPx in spermatozoa is correlated with fertility-related parameters and their residual PHGPX protein activities can be used as a predictive marker for the patients's sperms remaining fertilization capacity.

\section{PRM-1/PRM-2 Expression and Sperm Chromatin Condensation as Male Fertility Markers}

Male infertility can be also associated with abnormal sperm chromatin condensation due to a lack of protamines [231]. Protamines are the major DNA-binding proteins in the nucleus of sperms in most vertebrates, packaging the DNA in a volume less than $5 \%$ of a somatic cell nucleus. Many mammals have one protamine, but a few species, including humans and mice, have two. Mouse knock-out studies for both protamine genes have now shown that they are functional not redundant but that both protamines are essential for sperm chromatin condensation and that haploinsufficiency caused by a mutation in one allele of Prm-1 or Prm-2 prevents genetic transmission of both mutant and wild-type alleles [232]. It has now been shown in mice experimentally that protamines are indeed essential for 
compaction of the sperm nucleus and COMET assays have demonstrated that there is a direct correlation between the fraction of sperm with haploinsufficiency of Prm-2 and the frequency of sperm with damaged DNA [233]. As expected, ultrastructural analysis revealed reduced compaction of the sperm chromatin. ICSI with Prm-2-deficient sperms result in activation of most metaphase II-arrested mouse eggs, but only few were able to develop to the blastocyst stage. These findings suggest that the integrity of sperm DNA is also important for early embryonic development which fails if there is an increased damage of sperm DNA. Prm-2 protein is therefore one of the crucial gene products for maintaining the integrity of sperm chromatin.

Prm-2 deficient sperms have also reduced amounts of Prm-1 indicating that Prm-1 requires the normal amount of Prm-2 to become incorporated into sperm chromatin. These results raise the question whether also in human the ratio of protamine 1 (PRM-1) and protamine 2 (PRM-2) expression in the testis tissue can be a reliable prognostic marker, not only for the integrity of sperm chromatin and male fertility, but also for normal early embryonic development after fertilization. Abnormal sperm protamine levels are a common defect in infertility patients [173, 234] but ICSI fertilization and subsequent embryo cleavage have been found to be not different in patients without PRM-2 protein expression in sperms, although general effects of sperm nuclear DNA damage and altered chromatin structure on fertilization and embryo development have been reported [176]. All patients should therefore offered an analysis of the integrity of chromatin and DNA in the sperms especially if they suffer from a known mitochondrial disease or if the sperms are globozoospermic [175]. For this purpose a ubiquitin-based sperm quality assay has been developed recently [235], since it was found that morphologically bad sperms have been tagged by ubiquitin during their epididymal passage [236].

\section{THERAPEUTIC PERSPECTIVES FOR TREATMENT OF GENE DEFECTS CAUSING HUMAN MALE INFERTILITY}

Therapeutic concepts for the treatment of gene defects causing male infertility are still rare. The only examples are hormone replacement therapies in patients with a clinical picture of idiopathic hypogonadrotopic hypogonadism ( $\mathrm{IHH}$ syndromes) where the primary defect and reason for their infertility have been diagnosed in the hypothalamus or puitrary (e.g. Kallman syndrome; Reifenstein syndrome). Spermatogonia stem cells have the capacity to rejuvenate spermatogenesis after toxic insult in animal models. In principle, it should therefore be possible to re-initiate the spermatogenesis cycle in a man with severe infertility, independent from a genetic aetiology, as long as one is able to identify a spermatogonial stem cell in his testis tubules. A general therapeutic concept for all men which still have some stem cell spermatogonia in their testis tubules should therefore be possible [237]. However, first interspecies cross experiments with spermatogonia stem cells of macaques transferred to the empty testis tubules of a fertile rat displayed an interruption of the spermatogenesis cycle shortly after meiosis [238]. Molecular reasons for this draw back are most likely the rapid evolution rates of genes that are involved in the postmeiotic reproduction cycle [239]. Comparing 2.820 rodent genes with their homologous human genes, reproductive genes are found among the $10 \%$ most divergent sequences [48]. Postmeiotic maturation of the spermatogonia might therefore be only possible in the patient's own or in a human donor germ line.

\section{SHOULD THERAPEUTIC CONCEPTS TREATING MALE INFERTILITY BYPASS THE GENETIC DEFECT?}

It has become popular to bypass the patient's male infertility by using the ICSI protocol also after a genetic defect has been diagnosed causing the patient's infertility. However, recent descriptions of an increased rate of chromosome abnormalities in ICSI offspring [39] and a twice as high risk for major birth defects in IVF/ISCI offspring when compared with naturally conceived infants reported in a large Australian study [240] now put a serious question mark behind this practical decision.

A major concern is the largely unknown risk of transmitting not only the genetically caused male infertility to the ICSI offspring, but also some of the pleiotropic genetic syndromes discussed above with unpredictable somatic pathologies, because of the unknown "genetic load factor" of the ICSI embryo. One example which has been described in this review are the individuals with AZFc deletions which did display severe gonadal dysgenesis [107].

Another major concern are the safety aspects of ICSI and other ART protocols for the epigenetic control program of the human preimplantation embryo which is not yet well understood [241]. There is now first evidence that the disproportionate high number of low birth weights in offspring of assisted reproductive technology is not due to the higher rate of multiple gestations associated with ART but most likely due to imprinting defects [242]. The authors compared in their study only singletons: 42.463 infants who were born with ART and 3.389.098 infants born naturally. They found a significant increase of a low birth weight in the ART infants and this low-birth rate did not increase when comparing twins in both study groups.

Gene specific imprinting defects during fetal development, especially the occurrence of Angelman syndrome (AS), were reported recently to be associated with infants born after ICSI treatment [243]. AS (OMIM ref. No. 601623 ) is a neurogenetic disorder characterised by severe mental retardation, delayed motor development, poor balance and absence of speech. It is caused by loss of function of the maternal allele of the UBE3 gene located on chromosome 15 . The paternal allele is usually imprinted by methylation [244]. In both cases, exon 1 of the SNRPN gene which is part of the regulating imprinting center (IC) in this chromosome region (OMIM ref. No. 182279) was found to be hypomethylated [243]. Usually, AS is a rare disease (1:15.000 newborns) and imprinting defects account for only about $5 \%$ of all cases, i.e., after natural reproduction the incidence of a maternal methylation, as found in both ICSI cases, is usually not higher than 1:300.000. This suggests an over-representation of AS imprinting defects among children conceived by ICSI [243]. Both AS infants were conceived by a couple who sought ICSI because of the men's oligozoos- 
permia, which in one case was associated with a decrease of sperm motility and in the second case with hypogonadotropic hypogonadism. The pregnancies were uncomplicated.

A second imprinting disease probably also associated with ART was found with the Beckwith-Wiedemann syndrome mapped on the short arm of chromosome 11 (11p15:; BWS: MIM no 130650) [245]. The authors report of 6 children with BWS which have been born after ICSI. Five of them showed an abnormal imprinting (hypomethylation) of the LIT1 RNA within the $\mathrm{K}_{\mathrm{v}} \mathrm{LQT} 1$ gene locus (OMIM ref. no. 192500), one an abnormal imprinting (hypermethylation) of H19 RNA which controls the activation of the IGF2 gene [245]. In contrast to the Angelman syndrome, BWS is mainly caused by loss of imprinting (LOI) making it more difficult to postulate a causal relationship between ART and the occurrence of BWS. However, on the basis of a national BWS registry established by the authors in 2001, a six-fold increase of BWS in children born after ART, compared with the BWS rate in the general population, was estimated.

Since in both, AS and BWS ICSI infants, the maternal allele was affected, these imprinting defects seem to be not caused by some sperm defects but by some unknown disturbations of the maternal genome in the maturating oocyte or after the cytoplasmic injection of the sperm according to the ICSI protocol. One known causative agent impairing in vitro oocyte development are obviously suboptimal culture conditions used for the maturating oocytes, since differential effects of culture conditions on imprinted genes of the mouse preimplantation embryo have been reported [246]. However, in order to confirm or falsify the proposed ART-linked imprinting defects in IVF embryos a larger group of ICSI offspring needs to be studied for similar imprinting defects. For this purpose introduction of a prenatal methylation test for imprinted gene loci in all embryos conceived by ICSI might be required.

\section{ACKNOWLEDGEMENTS}

I like to thank all my friends and colleagues, especially Rüdiger Behr, Martin Bergmann, Paul Burgoyne, Jean Pierre Hardelin, Ilpo Huhtaniemi, Franklin Kieswetter, Martin Matzuk, Ewa Rajpert-De-Meyts, who have contributed with their ideas, opinions, and materials to different aspects of this review. Thomas Strowitzki is thanked for critical reading this manuscript and I am undebted to Mrs. Christine Mahrla for her help in preparing the final version of this manuscript. This study was supported by grants given from the Deutsche Forschungsgemeinschaft (DFG: Vo403/10-2; 11-5; 12-2).

\section{REFERENCES}

[1] World Health Organisation. Towards more objectivity in diagnosis and management of male infertility. Int J Andrology 1987; 7: 1-35.

[2] Hackstein JH, Hochstenbach R, Pearson PL. Towards an understanding of the genetics of human male infertility: lessons from flies. Trends Genet 2000; 16: 565-572.

[3] Cooke HJ, Saunders PT. Mouse models of male infertility. Nat Rev Genet 2002; 3: 790-801.

[4] Matzuk MM, Lamb DJ. Genetic dissection of mammalian fertility pathways. Nat Cell Biol 2002; 4: Suppl s41-49.

[5] Vogt PH. Molecular basis of male. (in)fertility. Int J Androl 1997; 20: Suppl3 2-10.
[6] Vogt PH. Genetic disorders of human infertility In: Encyclopedia of the human genome online. (Cooper DC, Ed, nature publishing group; reference \#520 in: http://ehgnaturereferencecom/ EHGheadwordshtm. 2003.

[7] Stenchever MA, Macintyre MN, Jarvis JA, Hempel JM. Cytogenetic studies of 32 infertile couples. Obstet Gynecol 1969; 33: 380-382.

[8] Van Assche E, Bonduelle M, Tournaye H, Joris H, Verheyen G, Devroey P, et al. Cytogenetics of infertile men. Hum Reprod 1996; 11: $1-24$.

[9] Tournaye H, Staessen C, Liebaers I, Van Assche E, Devroey P, Bonduelle $\mathrm{M}$, et al. Testicular sperm recovery in nine 47XXY Klinefelter patients Hum Reprod 1996; 11: 1644-1649.

[10] Foss GL, Lewis FJ. A study of four cases with Klinefelter's syndrome showing motile spermatozoa in their ejaculates. J Reprod Fertil 1971; 25: 401-408.

[11] Mroz K, Hassold TJ, Hunt PA. Meiotic aneuploidy in the XXY mouse: evidence that a compromised testicular environment increases in incidence meiotic errors. Hum Reprod 1999; 14: 11511156.

[12] Rapley EA, Crockford GP, Tear D, Biggs P, Seal S, Barfoot R, et al. Localization to Xq27 of a susceptibility gene for testicular germ-cell tumours. Nat Genet 2000; 24: 197-200.

[13] Berthelsen JG, Skakkebaek NE, Perboll O, et al. Electron microscopic demonstration of the extra $\mathrm{Y}$ chromosome in spermatocytes from human XYY males. In Development and function of reproductive organs 1981; Byskov AG, Peters H, Eds, Excerpta Medica: Amsterdam pp 328-337.

[14] Chandley AC, Gosden JR, Hargreave TB, Spowart G, Speed RM, McBeath S. Deleted Yq in the sterile son of a man with a satellited Y chromosome. (Yqa) J Med Gen 1989; 26: 145-153.

[15] Vogt PH. Human Y chromosome function in male germ cell development. Adv Dev Biol 1996; 4: 191-257.

[16] Fryns P, Kleczkowska A, Van den Berghe H. Clinical manifestation of Y/autosome translocations in man In Sandberg AA. (ed) The $\mathrm{Y}$ chromosome Part B: Clinical aspects of $\mathrm{Y}$ chromosome abnormalities. Alan R Liss Inc. New York. 1985; pp 213-243.

[17] Smith A, Fraser IS, Elliot G. An infertile male with balanced Y;19 translocation Review of Y; autosome translocations. Ann Genet 1979; 22: 189-194.

[18] Gonzales J, Lesourd S, Dutrillaux B. Mitotic and meiotic analysis of a reciprocal translocation $\mathrm{t}(\mathrm{Y} ; 3)$ in an azoospermic male. Hum Genet 1981; 57: 111-114.

[19] Viguié F, Romani F, Dadoune JP. Male infertility in a case of. $(\mathrm{Y} ; 6)$ balanced reciprocal translocation Mitotic and meiotic study. Hum Genet 1982; 62: 227-227.

[20] Armstrong SJ, Kirkham AJ, Hulten MA. XY chromosome behaviour in the germ-line of the human male: a FISH analysis of spatial orientation chromatin concensation and pairing. Chromosome Res 1994; 2: 445-452.

[21] Boucekkine C, Toublanc JE, Abbas N, Chaabouni S, Ouahid S, Semrouni M, et al. Clinical and anatomical spectrum in XX sex reversed patients Relationship to the presence of Y specific DNAsequences. Clin Endocrin 1994; 40: 733-742.

[22] Vogt PH. Genetic aspects of artificial fertilization. Hum Reprod 1995; 10: 128-137.

[23] Zühlke C, This U, Braulke I. Down syndrome and male fertility: PCR-derived fingerprinting serological and andrological investigations. Clin Genet1994; 46: 324-326.

[24] Chaganti RSK, Jhanwar SC, Ehrenbard LT, Kourides IA, Williams JJ. Genetically determined asynapsis spermatogenic degeneartion and infertility in men. Am J Hum Genet 1980; 32: 833-848.

[25] Egozcue S, Blanco J, Vendrell JM, Garcia F, Veiga A, Aran B, et al. Human male infertility: chromosome anomalies meiotic disorders abnormal spermatozoa and recurrent abortion. Hum Reprod Update 2000; 6: 93-105.

[26] Faraut T, Mermet MA, Demongeot J, Cohen O. Cooperation of selection and meiotic mechanisms in the production of imbalances in reciprocal translocations. Cytogenetics and Cell Genetics 2000; 88: $15-21$.

[27] Finkelstein S, Mukamel E, Yavetz H, Paz G, Avivi L. Increased rate of nondisjunction in sex cells derived from low-quality semen. Hum Genet 1998; 102: 129-137.

[28] Pfeffer J, Pang M-G, Hoegerman SF, Osgood CJ, Stacey MW, Mayer J, et al. Aneuploidy frequencies in semen fractions from ten 
oligoasthenoteratozoospermic patients donating sperm for intracytoplasmatic sperm injection. Fertil Steril 1999; 72: 472-478.

[29] Pang MG, Hoegerman SF, Cuticchia AJ, Moon SY, Doncel GF, Acos AA, et al. Detection of aneuploidy for chromosomes 46789 $10111213171821 \mathrm{X}$ and $\mathrm{Y}$ by fluorescence in-situ hybridization in spermatozoa from nine patients with oligoasthenoteratozoospermia undergoing intracytoplasmatic sperm injection. Hum Reprod 1999; 14: 1266-1273.

[30] Vegetti W, Van Assche E, Frias A, Verheyen G, Bianchi MM, Bonduelle $\mathrm{M}$, et al. Correlation between semen parameters and sperm aneuploidy rates investigated by fluorescence in-situ hybridization in infertile men. Hum Reprod 2000; 15: 351-365.

[31] Calogero AE, De Palma A, Grazioso C, Barone N, Romeo R, Rappazzo G, et al. Aneuploidy rate in spermatozoa of selected men with abnormal semen parameters. Hum Reprod 2001; 16: 11721179.

[32] Shi Q, Martin RH. Multicolor fluorescence in situ hybridization analysis of meiotic chromosome segregation in a 47XYY male and a review of the literature. Am J Med Genet 2000; 93: 40-46.

[33] Lewis-Jones I, Aziz N, Seshadri S, Douglas A, Howard P. Sperm chromosomal abnormalities are linked to sperm morphologic deformities. Fertil Steril 2003; 79: 212-215.

[34] Silber S, Escudero T, Lenahan K, Abdelhadi I, Kilani Z, Munne S. Chromosomal abnormalities in embryos derived from testicular sperm extraction. Fertil Steril 2003; 79: 30-38.

[35] Hassold T, Hunt P. To err. (meiotically) is human: the genesis of human aneuploidy. Genetic 2001; 2: 280-291.

[36] Pieters MH, Geraedts JP, Meyer H, Dumoulin JC, Evers JL, Jongbloed RJ, et al. Human gametes and zygotes studied by nonradioactive in situ hybridisation. Cytogenet Cell Genet 1990; 53: $15-19$.

[37] Eils R, Uhrig S, Saracoglu K, Satzler K, Bolzer A, Petersen I, et al. An optimized fully automated system for fast and accurate identification of chromosomal rearrangements by multiplex-FISH (M-FISH). Cytogenet Cell Genet 1998; 82: 160-171.

[38] Jorgensen AL. Alphoid repetitive DNA in human chromosomes. Dan Med Bull 1997; 44: 522-534.

[39] Bonduelle M, Van Assche E, Joris H, Keymolen K, Devroey P, Van Steirteghem A, et al. Prenatel testing in ICSI pregnancies: incidence of chromosomal anomalies in 1586 karyotypes and relation to sperm parameters. Hum Reprod 2002; 17: 2600-2614.

[40] Shi Q, Martin RH. Aneuploidy in human spermatozoa: FISH analysis in men with constitutional chromosomal abnormalities and in infertile men. Reproduction 2001; 121: 655-666.

[41] Madgar I, Dor J, Weissenberg R, Raviv G, Menashe Y, Levron J. Prognostic value of the clinical and laboratory evaluation in patients with nonmosaic Klinefelter syndrome who are receiving assisted reproductive therapy. Fertil Steril 2002; 77: 1167-1169.

[42] Rives N, Joly G, Machy A, Simeon N, Leclere P, Mace B. Assessment of sex chromosome aneuploidy in sperm nuclei from 47XXY and 46XY/47XXY males: comparison with fertil and infertile males with normal karyotype. Mol Hum Repod 2000; 6: 107-112.

[43] Moosani N, Chernos J, Lowry RB, Martin RH, Rademaker A. A 47XXY fetus resulting from ICSI in a man with an elevated frequency of 24XY spermatozoa. Hum Reprod 1999; 14: 11371138.

[44] Hennebicq S, Pelletier R, Bergues U, Rousseaux S. Risk of trisomy 21 in offspring of patients with Klinefelter's syndrome. Lancet 2001; 357: 2105-2105.

[45] Hassold T, Sherman S, Hunt P. Counting cross-overs: characterizing meiotic recombination in mammals. Hum Mol Genet 2000; 9: 2409-2419.

[46] Metzler-Guillemain C, Guichaoua M-R. A simple and reliable method for meiotic studies on testicular samples used for intracytoplasmic sperm injection. Fertil Steril 2000; 74 916-919.

[47] Armstrong SJ, Hultén MA. Meiotic segregation analysis by FISH investigations in sperm and spermatocytes of translocation heterozygotes. Europ J Human Genet 1998; 6: 430-431.

[48] Makalowski W, Boguski MS. Evolutionary parameters of the transcribed mammalian genome: an analysis of 2820 orthologous rodent and human sequences. Proc Natl Acad Sci USA 1998; 95: 9407-9412.

[49] Swanson WJ, Vacquier VD. The rapid evolution of reproductive proteins. Nat Rev Genet 2002; 3: 137-144.
[50] Vogel F, Motulsky AG. Mutation. In Human genetics SpringerVerlag: Berlin 1986; pp 334-432.

[51] Vogt PH. Human chromosome deletions in Yq11 AZF candidate genes and male infertility: history and update. Mol Hum Reprod 1998; 4: 739-744.

[52] Krausz C, McElreavey K. Y chromosome and male infertility. Front Biosci 1999; 4: E1-8.

[53] Oates RD, Amos JA. The genetic basis of congenital bilateral absence of the vas deferens and cystic fibrosis. J Androl 1994; 15: $1-8$.

[54] Tiepolo L, Zuffardi O. Localization of factors controlling spermatogenesis in the nonfluorescent portion of the human Y chromosome long arm. Hum Genet 1976; 28: 119-124.

[55] Reijo R, Alagappan RK, Patrizio P, Page DC. Severe oligozoospermia resulting from deletions of azoospermia factor gene on Y chromosome. Lancet 1996; 347: 1290-1293.

[56] Vogt PH, Edelmann A, Kirsch S, Henegariu O, Hirschmann P, Kiesewetter F, et al. Human Y chromosome azoospermia factors. (AZF) mapped to different subregions in Yq11. Hum Mol Genet 1996; 5: 933-943

[57] Kleiman SE, Yogev L, Gamzu R, Hauser R, Botchan A, Paz G, et al. Three-generation evaluation of Y-chromosome microdeletion. J Androl 1999; 20: 394-398.

[58] Saut N, Terriou P, Navarro A, Levy N, Mitchell MJ. The human Y chromosome genes BPY2 CDY1 and DAZ are not essential for sustained fertility. Mol Hum Reprod 2000; 6: 789-793.

[59] Calogero AE, Garofalo MR, Barone N, Longo GA, De Palma A, Fichera M, et al. Spontaneous transmission from a father to his son of a Y chromosome microdeletion involving the deleted in azoospermia. (DAZ) gene. J Endocrinol Invest 2002; 25: 631-634.

[60] Pryor JL, Kent-First M, Muallem A, Van Bergen AH, Nolten WE, Meisner L, et al. Microdeletions in the $\mathrm{Y}$ chromosome of infertile men. N Engl J Med 1997; 20: 534-539.

[61] Krausz C, Quintana-Murci L, McElreavey K. Prognostic value for Y deletion analyses: what is the clinical prognostic value of $\mathrm{Y}$ chromosome microdeletion analysis? Hum Reprod 2000; 15: 14311434.

[62] Simoni M. Molecular diagnosis of Y chromosome microdeletions in Europe: state-of-the-art and quality control. Hum Reprod 2001; 16: 403-409.

[63] Chen KS, Manian P, Koeuth T, Potocki L, Zhao Q, Chinault AC, et al. Homologous recombination of a flanking repeat gene cluster is a mechanism for a common contiguous gene deletion syndrome. Nat Genet 1997; 17: 154-163.

[64] Tilford CA, Kuroda-Kawaguchi T, Skaletsky H, Rozen S, Brown LG, Rosenberg M, et al. A physical map of the human $\mathrm{Y}$ chromosome. Nature 2001; 409: 943-945.

[65] Kuroda-Kawaguchi T, Skaletzsky H, Brown LG, Minx PJ, Cordum $\mathrm{H}$, Waterston RH, et al. The AZFc region of the Y chromosome features massive palindromes and uniform recurrent deletions in infertile men. Nat Genet 2001; 29: 279-286.

[66] Blanco P, Shlumukova M, Sargent CA, Jobling MA, Affara N, Hurles ME. Divergent outcomes of intrachromosomal recombination on the human Y chromosome: male infertility and recurrent polymorphism. J Med Genet 2000; 37: 752-758.

[67] Kamp C, Hirschmann P, Voss H, Huellen K, Vogt PH. Two long homologous retroviral sequence blocks in proximal Yq11 cause AZFa microdeletions as a result of intrachromosomal recombination events. Hum Mol Genet 2000; 9: 2563-2572.

[68] Sun C, Skaletsky H, Rozen S, Gromoll J, Nieschlag E, Oates R, et al. Deletion of azoospermia factor a. (AZFa) region of human $\mathrm{Y}$ chromosome caused by recombination between HERV15 proviruses Hum Mol Genet 2000; 9: 2291-2296

[69] Repping S, Skaletsky H, Lange J, Silber S, Van Der Veen F, Oates $\mathrm{RD}$, et al. Recombination between palindromes P5 and P1 on the human $\mathrm{Y}$ chromosome causes massive deletions and spermatogenic failure. Am J Hum Genet 2002; 71: 906-922.

[70] Akgun E, Zahn J, Baumes S, Brown G, Liang F, Romanienko PJ, et al. Palindrome resolution and recombination in the mammalian germ line. Mol Cell Biol 1997;17: 5559-5570.

[71] Lahn BT, Page DC. Functional coherence of the human Y chromosome. Science 1997; 278: 675-679.

[72] Vogt PH, Affara N, Davey P, Hammer M, Jobling MA, Lau Y-FC, et al. Report on the third international workshop on Y chromosome mapping 1997. Cytogenetics and Cell Genetics 1997; 79: 1-20. 
[73] Murphy WJ, Sun S, Chen ZQ, Pecon-Slattery J, O'Brien SJ. Extensive conservation of sex chromosome organization between cat and human revealed by parallel radiation hybrid mapping. Genome Res 1999; 9: 1223-1230.

[74] Qureshi SJ, Ross AR, Ma K, Cooke HJ, Intyre MA, Chandley AC, et al. Polymerase chain reaction screening for $\mathrm{Y}$ chromosome microdeletions: a first step towards the diagnosis of geneticallydetermined spermatogenic failure in men. Mol Hum Reprod 1996; 2: 775-779.

[75] Foresta C, Ferlin A, Garolla A, Rossato M, Barbaux S, De Bortoli A. Y-chromosome deletions in idiopathic severe testiculopathies. J Clin Endocrinol Metab 1997; 82: 1075-1080.

[76] Luetjens CM, Gromoll J, Engelhardt M, Von Eckardstein S, Bergmann M, Nieschlag E, et al. Manifestation of Y-chromosomal deletions in the human testis: a morphometrical and immunohistochemical evaluation. Hum Reprod 2002; 17: 22582266.

[77] Ferlin A, Moro E, Rossi A, Dallapiccola B, Foresta C. The human $\mathrm{Y}$ chromosome's azoospermia factor $\mathrm{b}$. (AZFb) region: sequence structure and deletion analysis in infertile men. J Med Genet 2003; 40: $18-24$.

[78] Xu J, Burgoyne S, Arnold AP. Sex differences in sex chromosome gene expression in mouse brain. Hum Mol Genet 2002; 11: 14091419.

[79] Mahadevaiah SK, Odorisio T, Elliott DJ, Rattigan A, Szot M, Laval SH, et al. Mouse homologues of the human AZF candidate gene RBM are expressed in spermatogonia and spermatids and map to a Y chromosome deletion interval associated with a high incidence of sperm abnormalities. Hum Mol Genet 1998; 7: 715727.

[80] Elliott DJ, Millar MR, Oghene K, Ross A, Kiesewetter F, Pryor J, et al. Expression of RBM in the nuclei of human germ cells is dependent on a critical region of the Y chromosome long arm. Proc Natl Acad Sci USA 1997; 94: 3848-3853.

[81] Mazeyrat S, Saut N, Grigoriev V, Mahadevaiah SK, Ojarikre OA, Rattigan A, et al. A Y-encoded subunit of the translation initiation factor Eif2 is essential for mouse spermatogenesis. Nat Genet 2001; 29: 49-53.

[82] Gogarten JP, Olendzenski L. Orthologs paralogs and genome comparisons. Curr Opin Genet Dev 1999; 9: 630-636.

[83] Shan Z, Hirschmann P, Seebacher T, Edelmann A, Jauch A, Morell $\mathrm{J}$, et al. A SPGY copy homologous to the mouse gene Dazla and the Drosophila gene boule is autosomal and expressed only in the human male gonad. Hum Mol Genet 1996; 5: 2005-2011.

[84] Seboun E, Barbaux S, Bourgeron T, Nishi S, Agulnik A, Egashira $\mathrm{M}$, et al. Gene sequence localization and evolutionary conservation of DAZLA a candidate male sterility gene. Genomics 1997;41: 227-235.

[85] Lahn BT, Page DC. Retroposition of autosomal mRNA yielded testis-specific gene family on human Y chromosome. Nat Genet 1999; 21: 429-433.

[86] Sun C, Skaletsky H, Birren B, Devon K, Tang Z, Silber S, et al. An azoospermic man with a de novo point mutation in the $\mathrm{Y}$ chromosome gene USP9Y. Nat Genet 1999; 23: 429-432.

[87] Rolf C, Gromoll J, Simoni M, Nieschlag E. Natural transmission of a partial $\mathrm{AZFb}$ deletion of the $\mathrm{Y}$ chromosome over three generations: case report. Hum Reprod 2002; 17: 2267-2271.

[88] Prosser J, Inglis JD, Condie A, Ma K, Kerr S, Thakrar R, et al. Degeneracy in human multicopy RBM. (YRRM) a candidate spermatogenesis gene. Mamm Genome 1996; 7: 835-842.

[89] Fernandes S, Huellen K, Goncalves J, Dukal H, Zeisler J, Rajpert De Meyts E, et al. High frequency of DAZ1/DAZ2 gene deletions in patients with severe oligozoospermia. Mol Hum Reprod 2002; 8: 286-298.

[90] Stuppia L, Calabrese G, Franchi PG, Mingarelli R, Gatta V, Palka $\mathrm{G}$, et al. Widening of a Y-chromosome inteval-6 deletion transmitted from a father to his infertile son accounts for an oligozoospermia criterial region distal to the RBM1 and DAZ genes. Am J Hum Genet 1996; 59: 1393-1395.

[91] MHC sequencing consortium. Complete sequence and gene map of a human major histocompatibility complex. Nature 1999; 401: 921923.

[92] Vogt MH, de Paus RA, Voogt PJ, Willemze R, Falkenburg JH. DFFRY codes for a new human male-specific minor transplantation antigen involved in bone marrow graft rejection. Blood 2000a; 95: 1100-1105.
[93] Vogt HHJ, van den Muijsenberg JW, Goulmy E, Spierings E, Kluck P, Kester MG, et al. The DBY gene codes for an HLA-DQ5restricted human male-specific minor histocompatibility antigen involved in graft-versus-host disease. Blood 2002; 99: 3027-3032.

[94] Vogt MHJ, Goulmy E, Kloosterboer FM, Blokland E, de Paus RA, Willemze R, et al. UTY gene codes for an HLA-B60-restricted human male-specific minor histocompatibility antigen involved in stem cell graft rejection: characterization of the critical polymorphic amino acid residues for T-cell recognition. Blood 2000b; 96: 3126-3132.

[95] Warren EH, Gavin MA, Simpson E, Chandler P, Page DC, Disteche C, et al. The human UTY gene encodes a novel HLA-B8restricted H-Y antigen. J Immunol 2000; 164: 2807-2814.

[96] Wang W, Meadows LR, den Haan JM, Sherman NE, Chen Y, Blokland E, et al. Human H-Y: a male-specific histocompatibility antigen derived from the SMCY protein. Science 1995; 269: 15881590 .

[97] Meadows L, Wang W, den Haan JM, Blokland E, Reinhardus C, Drijfhout JW, et al. The HLA-A*0201-restricted H-Y antigen contains a posttranslationally modified cysteine that significantly affects T cell recognition. Immunity 1997; 6: 273-281.

[98] Ohno S, Nagai Y, Ciccarese S, Iwata H. Testis-organizing H-Y antigen and the primary sex-determining mechanism of mammals. Recent Prog Horm Res 1997; 35: 449-476.

[99] O'Reilly AJ, Affara NA, Simpson E, Chandler P, Goulmy E, Ferguson-Smith MA. A molecular deletion map of the $\mathrm{Y}$ chromosome long arm defining $\mathrm{X}$ and autosomal homologous regions and the localisation of the HYA locus to the proximal region of the Yq euchromatin. Hum Mol Genet 1992; 1: 379-385.

[100] Goldberg EH. H-Y antigen and sex determination. Philos Trans R Soc B Biol Sci 1988; 322: 73-81.

[101] Kent-First MG, Kol S, Muallem A, Ofir R, Manor D, Blazer S, et al. The incidence and possible relevance of Y-linked microdeletions in babies born after intracytoplasmic sperm injection and their infertile fathers. Mol Hum Reprod 1996; 2: 943950.

[102] Page DC, Silber S, Brown LG. Men with infertility caused by AZFc deletion can produce sons by intracytoplasmic sperm injection but are likely to transmit the deletion and infertility. Hum Reprod 1999; 14: 1722-1726.

[103] Oates RD, Silber S, Brown LG, Page DC. Clinical characterization of 42 oligospermic or azoospermic men with microdeletion of the $\mathrm{AZFc}$ region of the $\mathrm{Y}$ chromosome and of 18 children conceived via ICSI. Hum Reprod 2002; 17: 2813-2824.

[104] Siffroi JP, Bourhis C, Krausz C, Barbaux S, Quintana-Murci L, Kanafani S, et al. Sex chromosome mosaicism in males carrying $Y$ chromosome long arm deletions. Hum Reprod 2000; 15: 25592562.

[105] Jaruzelska J, Korcz A, Wojda A, Jedrzejczak P, Bierla J, Surmacz $\mathrm{T}$, et al. Mosaicism for $45 \mathrm{X}$ cell line may accentuate the severity of spermatogenic defects in men with AZFc deletion. J Med Genet 2001; 38: 798-802.

[106] Papadimas J, Goulis DG, Giannouli C, Papanicolaou A, Tarlatzis B, Bontis JN. Ambiguous genitalia 45X/46XY mosaic karyotype and $\mathrm{Y}$ chromosome microdeletions in a 17 -year-old man. Fertil Steril 2001; 76: 1261-1263.

[107] Patsalis PC, Sismani C, Quintana-Mursi L, Taleb-Bekkouche F, Krausz C, McElreavey K. Effects of transmission of $\mathrm{Y}$ chromosome AZFc deletions. Lancet 2002; 360: 1222-1224.

[108] Chang HJ, Clark RD, Bachman H. The phenotype of 45X/46XY mosaicism: an analysis of 92 prenatally diagnosed cases. Am J Hum Genet 1990; 46: 156-167.

[109] Riordan JR, Rommens JM, Kerem B, Alon N, Rozmahel R, Grzelczak Z, et al. Identification of the cystic fibrosis gene: cloning and characterization of complementary DNA. Science 1989; 245: 1066-1073.

[110] Haardt M, Benharouga M, Lechardeur D, Kartner N, Lukacs GL. C-terminal truncations destabilize the cystic fibrosis transmembrane conductance regulator without impairing its biogenesis A novel class of mutation. J Biol Chem 1999; 274: 21873-21877.

[111] Bobadilla JL, Macek M Jr, Fine JP, Farrell PM. Cystic fibrosis: a worldwide analysis of CFTR mutations - correlation with incidence data and application to screening. Hum Mutat 2002; 19: 575-606.

[112] Estivill X. Complexity in a monogenic disease. Nature Genet 1996; 12: $348-50$. 
[113] Girodon E, Cazeneuve C, Lebargy F, Chinet T, Costes B, Ghanem $\mathrm{N}$, et al. CFTR gene mutations in adults with disseminated bronchiectasis. Eur J Hum Genet 1997; 5: 149-155.

[114] Pier GB. CFTR mutations and host susceptibility to Pseudomonas aeruginosa lung infection. Curr Opin Microbiol 2002; 5: 81-86.

[115] Jarvi K, Zielenski J, Wilschanski M, Durie P, Buckspan M, Tullis $\mathrm{E}$, et al. Cystic fibrosi: transmembrane conductance regulator and obstructive azoospermia. Lancet 1995; 345: 1578.

[116] Hargreave TB. Genetic basic of male fertility. Br Med Bull 2000 56: 650-671.

[117] Kiesewetter S, Macek M Jr, Davis C, Curristin SM, Chu CS, Graham C, et al. A mutation in CFTR produces different phenotypes depending on chromosomal background. Nat Genet 1993; 5: 274-278.

[118] Zielenski J, Patrizio P, Corey M, Handelin B, Markiewicz D, Asch $\mathrm{R}$, et al. CFTR gene variant for patients with congenital absence of vas deferens. Am J Hum Genet 1995; 57: 958-960.

[119] Patrizio P, Asch RH, Handelin B, Silber SJ. Aetiology of congenital absence of vas deferens: genetic study of three generations. Hum Reprod 1993; 8: 215-220.

[120] Cuppens H, Teng H, Raeymaekers P, De Boeck C, Cassiman JJ. CFTR haplotype backgrounds on normal and mutant CFTR genes. Hum Mol Genet 1994; 3: 607-614.

[121] Cuppens H, Lin W, Jaspers M, Costes B, Teng H, Vankeerberghen A, et al. Polyvariant mutant cystic fibrosis transmembrane conductance regulator genes. J Clin Invest 1998; 101: 487-496.

[122] Teng H, Jorissen M, Van Poppel H, Legius E, Cassiman JJ, Cuppens H. Increased proportion of exon 9 alternatively spliced CFTR transcripts in vas deferens compared with nasal epithelial cells. Hum Mol Genet 1997; 6: 85-90.

[123] Ferrie RM, Schwarz MJ, Robertson NH, Vaudin S, Super M, Malone G, et al. Development multiplexing and application of ARMS tests for common mutations in the CFTR gene. Am J Hum Genet 1992; 51: 251-262.

[124] Fonknechten N, Chelly J, Lepercq J, Kahn A, Kaplan JC, Kitzis A, et al. CFTR illegitimate transcription in lymphoid cells: quantification and applications to the investigation of pathological transcripts. Hum Genet 1992; 88: 508-512.

[125] Dequeker E, Cassiman JJ. Evaluation of CFTR gene mutation testing methods in 136 diagnostic laboratories: report of a large European external quality assessment. Eur J Hum Genet 1998; 6: 165-175.

[126] Dequeker E, Cuppens H, Dodge J, Estivill X, Goossens M, Pignatti $\mathrm{PF}$, et al. Recommendations for quality improvement in genetic testing for cystic fibrosis European Concerted Action on Cystic Fibrosis. Eur J Hum Genet 2000; 8: Suppl 2 S2-24.

[127] von Eckardstein S, Cooper TG, Rutscha K, Meschede D, Horst J, Nieschlag E. Seminal plasma characteristics as indicators of cystic fibrosis transmembrane conductance regulator. (CFTR) gene mutation in men with obstructive azoospermia. Fertil Steril 2000; 73: $1226-1231$.

[128] Suarez-Quian CA, Martinez-Garcia F, Nistal M, Regadera J. Androgen receptor distribution in adult human testis. J Clin Endocrinol Metab 1999; 84: 350-358.

[129] Heinlein AA, Chang C. Androgen receptor. (AR) coregulators: an overview. Endocr Rev 2002; 23: 175-200.

[130] Tut TG, Ghadessy FJ, Trifiro MA, Pinsky L, Yong EL. Long polyglutamine tracts in the androgen receptor are associated with reduced trans-activation impaired sperm production and male infertility. J Clin Endocrinol Metab 1997; 82: 3777-3782

[131] Patrizio P, Leonard DG, Chen KL, Hernandez-Ayup S, Trounson AO. Larger trinucleotide repeat size in the androgen receptor gene of infertile men with extremely severe oligozoospermia. J Androl 2001; 22: 444-448.

[132] Casella R, Maduro MR, Misfud A, Lipshultz LI, Yong EL, Lamb DJ. Androgen receptor gene polyglutamine length is associated with testicular histology in infertile patients. J Urol 2003; 169: 224227.

[133] Hiort O, Holterhus P-M. Androgen insensitivity and male infertility. Int J Androl 2003; 26: 16-20.

[134] Rajpert-De Meyts E, Leffers H, Petersen JH, Andersen AG, Carlsen Jorgensen N, Skakkebaek NE. CAG repeat length in androgen-receptor gene and reproductive variables in fertile and infertile men. Lancet 2002; 5: 44-46.

[135] Dadze S, Wieland C, Jakubiczka S, Funke K, Schroder E, RoyerPokora $\mathrm{B}$, et al. The size of the CAG repeat in exon 1 of the androgen receptor gene shows no significant relationship to impaired spermatogenesis in an infertile Caucasoid sample of German origin. Mol Hum Repod 2000; 6: 207-214.

[136] Thangaraj K, Joshi MB, Reddy AG, Gupta NJ, Chakravarty B, Sing L. CAG repeat expansion in the androgen receptor gene is not associated with male infertility in Indian populations. J Androl 2002; 23: 815-818.

[137] La Spada AR, Wilson EM, Lubahn DB, Harding AE, Fischbeck $\mathrm{KH}$. Androgen receptor gene mutations in X-linked spinal and bulbar muscular atrophy. Nature 1991; 352: 77-79.

[138] Yong EL, Lim LS, Wang Q, Mifsud A, Lim J, Ong YC, et al. Androgen receptor polymorphisms and mutations in male infertility. J Endocrinol Invest 2000; 23: 573-577.

[139] Yong EL, Ng SC, Roy AC, Yun G, Ratnam SS. Pregnancy after hormonal correction of severe spermatogenic defect due to mutation in androgen receptor gene Lancet 1994; 344: 826-827.

[140] Grewal RP, Leeflang EP, Zhang L, Arnheim N. The mutation properties of spinal and bulbar muscular atrophy disease alleles. Neurogenetics 1998; 1: 249-252.

[141] Vogt PH. Risk of neurodegenerative diseases in children conceived by intracytoplasmatic sperm injection? Lancet 1999; 354: 611-612

[142] Aittomaki K. FSH receptor defects and reproduction. In Fertility and Reproductive Medicine 1998; Kempers RD, Cohen J, Haney AF, Younger JB Eds, Elsevier Science BV: Amsterdam pp 761788.

[143] Tapanainen JS, Aittomaki K, Min J, Vaskivuo T, Huhtaniemi IT. Men homozygous for an inactivating mutation of the folliclestimulating hormone. (FSH) receptor gene present variable suppression of spermatogenesis and fertility. Nat Genet 1997; 15: 205-206.

[144] Abel MH, Wootton AN, Wilkins V, Huhtaniemi I, Knight PG, Charlton HM. The effect of a null mutation in the folliclestimulating hormone receptor gene on mouse reproduction. Endocrinology 2000; 141: 1795-1803.

[145] Simoni M, Nieschlag E, Gromoll J. Isoforms and single nucleotide polymorphisms of the FSH receptor gene: implications for human reproduction. Hum Reprod Update 2002; 8: 413-421.

[146] Sultan C, Lumbroso S. LH receptor defects. In Fertility and Reproductive Medicine Kempers RD, Cohen J, Haney AF, Younger JB Eds, Elsevier Science BV: Amsterdam 1998; pp 769782 .

[147] Kremer H, Mariman E, Otten BJ, Moll GW Jr, Stoelinga GB, Wit $\mathrm{JM}$, et al. Cosegregation of missense mutations of the luteinizing hormone receptor gene with familial male-limited precocious puberty. Hum Mol Genet 1993; 2: 1779-1783.

[148] Achermann JC, Weiss J, Lee EJ, Jameson JL. Inherited disorders of the gonadotropin hormones. Mol Cell Endocrinol 2001; 179: 89-96.

[149] Franco B, Guioli S, Pragliola A, Incerti B, Bardoni B, Tonlorenzi $\mathrm{R}$, et al. A gene deleted in Kallmann's syndrome shares homology with neural cell adhesion and axonal path-finding molecules. Nature 1991; 353: 529-536.

[150] Legouis R, Hardelin JP, Levilliers J, Claverie JM, Compain S, Wunderle V, et al. The candidate gene for the X-linked Kallmann syndrome encodes a protein related to adhesion molecules. Cell 1991; 67: 423-435.

[151] Del Castillo I, Cohen-Salmon M, Blanchard S, Lutfalla G, Petit C. Structure of the X-linked Kallmann syndrome gene and its homologous pseudogene on the Y chromosome. Nat Genet 1992; 2: 305-310.

[152] Bulow HE, Berry KL, Topper LH, Peles E, Hobert O. Heparan sulfate proteoglycan-dependent induction of axon branching and axon misrouting by the Kallmann syndrome gene kal-1. Proc Natl Acad Sci USA 2002; 99: 6346-6351.

[153] Hardelin JP. Kallmann syndrome: towards molecular pathogenesis. Mol Cell Endocrinol 2001; 179: 75-81.

[154] Hardelin JP, Levilliers J, del Castillo I, Cohen-Salmon M, Legouis R, Blanchard S, et al. X chromosome-linked Kallmann syndrome: stop mutations validate the candidate gene. Proc Natl Acad Sci USA 1992; 89: 8190-8194.

[155] Bick D, Franco B, Sherins RJ, Heye B, Pike L, Crawford J, et al. Brief report: intragenic deletion of the KALIG-1 gene in Kallmann's syndrome. N Engl J Med 1992; 326: 1752-1755.

[156] Dode C, Levilliers J, Dupont JM, De Paepe A, Le Du N, SoussiYanicostas N, et al. Loss-of-function mutations in FGFR1 cause autosomal dominant Kallmann syndrome. Nat Genet 2003; 33: 463-465. 
[157] Quinton R, Duke VM, de Zoysa PA, Platts AD, Valentine A, Kendall B, et al. The neuroradiology of Kallmann's syndrome: a genotypic and phenotypic analysis. J Clin Endocrinol Metab 1996; 81: 3010-3017.

[158] Habiby RL, Boepple P, Nachtigall L, Sluss PM, Crowley WF Jr, Jameson JL. Adrenal hypoplasia congenita with hypogonadotropic hypogonadism: evidence that DAX-1 mutations lead to combined hypothalmic and pituitary defects in gonadotropin production. J Clin Invest 1996; 98: 1055-1062.

[159] Seminara SB, Oliveira LM, Beranova M, Hayes FJ, Crowley WF Jr. Genetics of hypogonadotropic hypogonadism. J Endocrinol Invest 2000; 23: 560-565.

[160] Rott HD. Kartagener's syndrome and the syndrome of immotile cilia. Hum Genet 1979; 46: 249-261.

[161] Afzelius BA, Mossberg B. The metabolic and molecular bases of inherited disease. Scriver CR, Beaudet AL and Sly WS, Eds, McGraw-Hill: New York 1995; pp 3943-3954..

[162] Samuel I. Kartagener's syndrome with normal spermatozoa. JAMA 1987; 258: 1329-1330.

[163] Narayan D, Krishnan SN, Upender M, Ravikumar TS, Mahoney MJ, Dolan TF Jr, et al. Unusual inheritance of primary ciliary dyskinesia. (Kartagener's syndrome). J Med Genet 1994; 31: 493496.

[164] Blouin JL, Meeks M, Radhakrishna U, Sainsbury A, Gehring C, Sail GD, et al. Primary ciliary dyskinesia: a genome-wide linkage analysis reveals extensive locus heterogeneity. Eur J Hum Genet 2000; 8: 109-118.

[165] Pennarun G, Escudier E, Chapelin C, Bridoux AM, Cacheux V, Roger G, et al. Loss-of-function mutations in a human gene related to Chlamydomonas reinhardtii dynein IC78 result in primary ciliary dyskinesia. Am J Hum Genet 1999; 65: 1508-1519.

[166] Olbrich H, Haffner K, Kispert A, Volkel A, Volz A, Sasmaz G, et al. Mutations in DNAH5 cause primary ciliary dyskinesia and randomization of left-right asymmetry. Nat Genet 2002; 30: 143144.

[167] Bartoloni L, Blouin J-L, Pan Y, Gehrig C, Maiti AK, Scamuffa N, et al. Mutations in the DNAH11. (axonemal heavy chain dynein type 11) gene cause form of situs inversus totalis and most likely primary ciliary dyskinesia. Proc Natl Acad Sci USA 2002; 99: 10282-10286.

[168] Dutcher SK. Flagellar assembly in two hundred and fifty easy-tofollow steps. Trends 1995; 11: 389-404.

[169] Florke-Gerloff S, Topfer-Petersen E, Muller-Esterl W, Mansouri A, Schatz R, Schirren C, et al. Biochemical and genetic investigation of round-headed spermatozoa in infertile men including two brothers and their father. Andrologia 1994; 16: 187-202.

[170] Singh G. Ultrastructural features of round-headed human spermatozoa. Int J Fertil 1992; 37: 99-102.

[171] Carrell DT, Emery BR, Liu L. Characterization of aneuploidy rates protamine levels ultrastructure and functional ability of roundheaded sperm from two siblings and implications for intracytoplasmic sperm injection. Fertil Steril 1999; 71: 511-516.

[172a] Carrell DT, Liu L. Altered protamine 2 expression is uncommon in donors of known fertility but common among men with poor fertilizing capacity and may reflect other abnormalities of spermiogenesis. J Androl 2001; 22: 604-610.

[172b] Carrell DT, Wilcox AL, Udoff LC, Thorp C, Campbell B. Chromosome 15 aneuploidy in the sperm and conceptus of a sibling with variable familial expression of round-headed sperm syndrome. Fertil Sertil 2001; 76: 1258-1260.

[173] Viville S, Mollard R, Bach ML, Falquet C, Gerlinger P, Warter S. Do morphological anomalies reflect chromosomal aneuploidies?: Case report. Hum Reprod 2000; 15: 2563-2566.

[174] Vicari E, Perdichizzi A, De Palma A, Burrello N, D'Agata R, Calogero AE. Globozoospermia is associated with chromatin structure abnormalities: case report. Hum Reprod 2002; 17: 21282133.

[175] Sakkas D, Urner F, Bizzaro D, Manicardi G, Bianchi PG, Shoukir $\mathrm{Y}$, et al. Sperm nuclear DNA damage and altered chromatin structure: effect on fertilization and embryo development. Hum Reprod 1998; 13: Suppl 4 11-19.

[176] Adham IM, Emmen JM, Engel W. The role of the testicular factor INSL3 in establishing the gonadal position. Mol Cell Endocrinol 2000; 160: 11-16.

[177] Nef S, Parada LF. Cryptorchidism in mice mutant for Ins13. Nat Genet 1999; 22: 295-299.
[178] Tomboc M, Lee PA, Mitwally MF, Schneck FX, Bellinger M, Witchel SF. Insulin-like 3/relaxin-like factor gene mutations are associated with cryptorchidism. J Clin Endocrinol Metab 2000; 85: 4013-4018.

[179] Kumagai J, Hsu SY, Matsumi H, Roh JS, Fu P, Wade JD, et al. INSL3/Leydig insulin-like peptide activates the LGR8 receptor important in testis descent J Biol Chem 2002; 277: 31283-31286.

[180] Gorlov IP, Kamat A, Bogatcheva NV, Jones E, Lamb DJ, Truong A, et al. Mutations of the GREAT gene cause cryptorchidism. Hum Mol Genet 2002; 11: 2309-2318

[181] Moreno-Garcia M, Miranda EB. Chromosomal anomalies in cryptorchidism and hypospadias. J Urol 2002; 168: 2170-2172.

[182] Groenen P and Wieringa B. Expanding complexity in myotonic dystrophy. BioEssay 1998; 20: 901-912.

[183] Takeda R, Ueda M. Pituitary-gonadal function in male patients with myotonic dystrophy- serum luteinizing hormone follicle stimulating hormone and testosterone levels and histological dmaage of the testis. Acta Endocrinol. (Copenh) 1977; 84: 382389.

[184] Hortas ML, Castilla JA, Gil MT, Molina J, Garrido ML, Morell M, et al. Decreased sperm function of patients with myotonic muscular dystrophy. Hum Reprod 2000; 15: 445-448.

[185] Zullo SJ, Butler L, Zahorchak RJ, Macville M, Wilkes C, Merril $\mathrm{CR}$. Localization by fluorescence in situ hybridization. (FISH) of human mitochondrial polymerase gamma. (POLG) to human chromosome band 15q24-->q26 and of mouse mitochondrial polymerase gamma. (Polg) to mouse chromosome band 7E with confirmation by direct sequence analysis of bacterial artificial chromosomes. (BACs) Cytogenet Cell Genet 1997; 78: 281-284.

[186] Rovio A, Tiranti V, Bednarz AL, Suomalainen A, Spelbrink JN, Lecrenier N, et al. Analysis of the trinucleotide CAG repeat from the human mitochondrial DNA polymerase gene in healthy and diseased individuals. Eur J Hum Genet 1999; 7: 140-146.

[187] Rovio AT, Marchington DR, Donat S, Schuppe H-C, Abel J, Fritsche E, et al. Mutations at the mitochondrial DNA polymerase. (POLG) locus associated with male infertility. Nature Genetics 2001; 29: 261-262.

[188] Kao SH, Chao HT, Wei YH. Mitochondrial deoxyribonuclei acid 4977-bp deletion is associated with diminished fertility and motility of human sperm. Biology of Reproduction 1995; 52: 729-736.

[189] Kao SH, Chao HT, Wei YH. Multiple deletions of mitochondrial DNA are associated with the decline of motility and fertility of human spermatozoa. Mol Hum Reprod 1998; 4: 657-666.

[190] St John JC, Jokhi RP, Barratt CL. Men with oligoasthenoteratozoospermia harbour higher numbers of multiple mitochondrial DNA deletions in their spermatozoa but individual deletions are not indicative of overall aetiology. Mol Hum Reprod 2001; 7: 103-111.

[191] O'Connell M, McClure N, Lewis SE. A comparison of mitochondrial and nuclear DNA status in testicular sperm from fertile men and those with obstructive azoospermia. Hum Reprod 2002; 17: 1571-1577.

[192] Ruiz-Pesini E, Lapena A, Diez-Sanchez C, Perez-Martos A, Enriquez J, Diaz M, et al. Human mitochondrial DNA haplogroups associated with high or reduced spermatozoa motility: Am J Hum Genet 2000; 67: 682-696.

[193] Cummins JM, Jequier AM, Kan R. Molecular biology of human male infertility: Links with aging mitochondrial genetics and oxidative stress? Mol Reprod Dev 1994; 37: 345-362.

[194] Wolf U. The genetic contribution to the phenotype. Hum Genet 1995; 95: 127-148.

[195] Badano JL, Katsanis N. Beyond mendel: an evolving view of human genetics disease transmission. Nature Genet 2002; 3: 779789.

[196] Friel A, Houghton JA, Glennon M, Lavery R, Smith T, Nolan A, et al. A preliminary report on the implication of RT-PCR detection of DAZ RBMY1 USP9Y and Protamine-2 mRNA in testicular biopsy samples from azoospermic men. Int J Androl 2002; 25: 5964.

[197] Lin YM, Chen CW, Sun HS, Tsai SJ, Hsu CC, Teng YN, et al. Expression patterns and transcript concentrations of the autosomal DAZL gene in testes of azoospermic men. Mol Hum Reprod 2001; 7: $1015-1022$

[198] Behr R, Weinbauer GF. cAMP response element modulator. (CREM): an essential factor for spermatogenesis in primates? Int $\mathrm{J}$ Androl 2001; 24: 126-135. 
[199] Kleiman SE, Lagziel A, Yogev L, Botchan A, Paz G, Yavetz H. Expression of CDY1 may identify complete spermatogenesis. Fertil Steril 2001; 75: 166-173.

[200] Hauser R, Botchan A, Yogev L, Gamzu R, Ben Yosef D, Lessing $\mathrm{JB}$, et al. Probability of sperm detection in nonobstructive azoospermic men undergoing testicular sperm extraction procedures unrelated to clinical parameters. Arch Androl 2002; 48: 301-305.

[201] Vernaeve V, Tournaye H, Schiettecatte J, Verheyen G, Van Steirteghem A, Devroey P. Serum inhibin B cannot predict testicular sperm retrieval in patients with non-obstructive azoospermia. Hum Reprod 2002; 17: 971-976.

[202] Venables JP, Eperon I. The roles of RNA-binding proteins in spermatogenesis and male infertility. Curr Opin Genet Dev 1999; 9: :346-54.

[203] Xu EY, Moore FL, Pera RA. A gene family required for human germ cell development evolved from an ancient meiotic gene conserved in metazoans. Proc Natl Acad Sci USA 2001; 98: $7414-$ 7419 .

[204] Grossmann B, Weinbauer G, Hirschmann P, Vogt PH. Conservation of the deleted-in-azoospermia-like-1. (DAZL1) gene structure in old world monkeys points to a homologous function of DAZL1 in this primate class. J Endocrinol Invest 2000; 23: 616622.

[205] Lin YM, Chen CW, Sun HS, Tsai SJ, Lin JS, Kuo PL. Presence of DAZL transcript and protein in mature human spermatozoa. Fertil Steril 2002; 77: 626-629.

[206] Habermann B, Mi HF, Edelmann A, Bohring C, Backert IT, Kiesewetter F, et al. DAZ. (Deleted in AZoospermia) genes encode proteins located in human late spermatids and in sperm tails. Hum Reprod 1998; 13: 363-369.

[207] Walker HW, Habener JF. Role of transcription factors CREB and CREM in cAMP-regulated transcription during spermatogenesis. Trends Endocrinol Metab 1996; 7: 133-138.

[208] Masquilier D, Foulkes NS, Mattei MG, Sassone-Corsi P. Human CREM gene: evolutionary conservation chromosomal localization and inducibility of the transcript. Cell Growth Differ 1993; 4: 931937.

[209] Foulkes NS, Mellstrom B, Benusiglio E, Sassone-Corsi P. Developmental switch of CREM function during spermatogenesis: from antagonist to activator. Nature 1992; 355: 80-84.

[210] Peri A, Serio M. The CREM system in human spermatogenesis. J Endocrinol Invest 2000; 23: 578-583.

[211] Gellersen B, Kempf R, Sandhowe R, Weinbauer GF, Behr R. Novel leader exons of the cyclic adenosine 3'5'-monophosphate response element modulator. (CREM) gene transcribed from promoters $\mathrm{P} 3$ and $\mathrm{P} 4$ are highly testis-specific in primates. Mol Hum Reprod 2002; 8: 965-976.

[212] Molina CA, Foulkes NS, Lalli E, Sassone-Corsi P. Inducibility and negative autoregulation of CREM: an alternative promoter directs the expression of ICER an early response repressor. Cell 1993; 75: 875-886.

[213] Fimia GM, De Cesare D, Sassone-Corsi P. CBP-independent activation of CREM and CREB by the LIM-only protein ACT. Nature 1999; 398: 165-169.

[214] Weinbauer GF, Behr R, Bergmann M, Nieschlag E. Testicular cAMP responsive element modulator. (CREM) protein is expressed in round spermatids but is absent or reduced in men with round spermatid maturation arrest. Mol Hum Reprod 1998; 4: 9-15.

[215] Steger K. Transcriptional and translational regulation of gene expression in haploid spermatids. Anat Embryol 1999; 199: 471487.

[216] Song GJ, Lee H, Park Y, Lee HJ, Lee YS, Seo JT, et al. Expression pattern of germ cell-specific genes in the testis of patients with nonobstructive azoospermia: usefulness as a molecular marker to predict the presence of testicular sperm Fertil Steril 2000; 73: 11041108.

[217] Lahn BT, Tang ZL, Zhou J, Barndt RJ, Parvinen M, Allis CD, et al. Previously uncharacterized histone acetyltransferases implicated in mammalian spermatogenesis. Proc Natl Acad Sci USA 2002; 99: 8707-8712.

[218] Meistrich ML, Trostle-Weige PK, Lin R, Bhatnagar YM, Allis CD. Highly acetylated $\mathrm{H} 4$ is associated with histone displacement in rat spermatids. Mol Reprod Dev 1992; 31: 170-181.

[219a] Krausz C, Quintana-Murci L, Rajpert-De Meyts E, Jorgensen N, Jobling MA, Rosser $\mathrm{ZH}$, et al. Identification of a Y chromosome haplogroup associated with reduced sperm counts. Hum Mol Genet 2001; 10: 1873-1877.

[219b] Krausz C, Rajpert-De Meyts E, Frydelund-Larsen L, QuintanaMurci L, McElreavey K, Skakkebaek NE. Double-blind Y chromosome microdeletion analysis in men with known sperm parameters and reproductive hormone profiles: microdeletions are specific for spermatogenic failure. J Clin Endocrinol Metab 2001; 86: 2638-2642.

[220] Simoni M, Bakker E, Eurlings MC, Matthijs G, Moro E, Muller $\mathrm{CR}$, et al. Laboratory guidelines for molecular diagnosis of Ychromosomal microdeletions. Int J Androl 1999; 22: 292-299.

[221] Kamp C, Huellen K, Fernandes S, Sousa M, Schlegel PN, Mielnik A, et al. High deletion frequency of the complete AZFa sequence in men with Sertoli-cell-only syndrome. Mol Hum Reprod 2001; 7: 987-994.

[222] Tournaye H. Surgical sperm recovery for intracytoplasmatic sperm injection which method is to be preferred? Hum Reprod 1999; 14: Suppl 1 71-81.

[223] Bukulmez O, Yucel A, Yarali H, Bildirici I, Gurgan T. The origin of spermatozoa does not affect intracytoplasmic sperm injection outcome. Eur J Obstet Gynecol Reprod Biol 2001; 94: 250-255.

[224] Ubaldi F, Nagy ZP, Rienzi L, Tesarik J, Anniballo R, Franco G, et al. Reproductive capacity of spermatozoa from men with testicular failure. Hum Reprod 1999; 14: 2796-2800.

[225] Pasqualotto FF, Rossi-Ferragut LM, Rocha CC, Iaconelli Jr A, Borges Jr E. Outcome of in vitro fertilization and intracytoplasmic injection of epididymal and testicular sperm obtained from patients with obstructive and nonobstructive azoospermia. J Urol 2002; 167: $1753-1756$.

[226] Kirchhoff C. Gene expression in the epididymis. Int Rev Cytol 1999; 188: 133-202.

[227] Kirchhoff C. The dog as a model to study human epididymal function at a molecular level. Mol Hum Reprod 2002; 8: 695-701.

[228] Ursini F, Heim S, Kiess M, Maiorino M, Roveri A, Wissing J, et al. Dual function of the selenoprotein PHGPx during sperm maturation. Science 1999; 285: 1393-1396.

[229] Kelner MJ, Montoya MA. Structural organization of the human selenium-dependent phospholipid hydroperoxide glutathione peroxidase gene. (GPX4): chromosomal localization to $19 \mathrm{p} 133$. Biochem Biophys Res Commun 1998; 249: 53-55.

[230] Foresta C, Flohé L, Garolla A, Roveri A, Ursini F, Maiorino M. Male fertility is linked to the selenoprotein phospholipid hydroperoxide glutathione peroxidase. Biol Reprod 2002; 67: 967971.

[231] Balhorn R, Reed S, Tanphaichitr N. Aberrant protamine 1/protamine 2 ratios in sperm of infertile human males. Experientia 1988; 44: 52-55.

[232] Cho C, Willis WD, Goulding EH, Jung-Ha H, Choi YC, Hecht NB, et al. Haploinsufficiency of protamine-1 or -2 causes infertility in mice. Nat Genet 2001; 28: 82-86.

[233] Cho C, Jung-Ha H, Willis WD, Goulding EH, Stein P, Xu Z, et al. Protamine-2 deficiency leads to sperm DNA damage and embryo death in mice. Biol Reprod 2003; 68: (5) [in press].

[234] Belokopytova IA, Kostyleva EI, Tomilin AN, Vorob'ev VI. Human male infertility may be due to a decrease of the protamine P2 content in sperm chromatin. Mol Reprod Dev 1993; 34: 53-57.

[235] Sutovsky P, Terada Y, Schatten G. Ubiquitin-based sperm assay for the diagnosis of male factor infertility. Hum Reprod 2001a; 16: 250-258.

[236] Sutovsky P, Moreno R, Ramalho-Santos J, Dominko T, Thompson WE, Schatten G. A putative ubiquitin-dependent mechanism for the recognition and elimination of defective spermatozoa in the mammalian epididymis. J Cell Sci 2001b; 114: 1665-1675.

[237] Brinster RL. Germline stem cell transplantation and transgenesis. Science 2002; 296: 2174-2176.

[238] Nagano M, Patrizio P, Brinster RL. Long-term survival of human spermatogonial stem cells in mouse testes. Fertil Steril 2002; 78: 1225-1233.

[239] Wyckoff GJ, Wang W, Wu CI. Rapid evolution of male reproduction genes in the descent of man. Nature 2000; 403: 304-309.

[240] Hansen M, Kurinczuk JJ, Bower C, Webb S. The risk of major birth defects after intracytoplasmic sperm injection and in vitro fertilization. N Engl J Med 2002; 346: 725-730.

[241] De Rycke M, Liebaers I, Van Steirteghem A. Epigenetic risks related to assisted reproduction technologies. Hum Reprod 2002; 17: 2487-2494. 
[242] Schieve LA, Meikle SF, Ferre C, Peterson HB, Jeng G, Wilcox LS. Low and very low birth weight in infants conceived with use of assisted reproductive technology. N Engl J Med 2002; 346: 731737.

[243] Cox GF, Bürger J, Lip V, Mau UA, Sperling K, Wu B-L, et al. Intracytoplasmic sperm injection may increase the risk of imprinting defects. Am J Human Genet 2002; 71: 162-164.

[244] Nicholls RD, Knepper JL. Genome organization function and imprinting in Prader-Willi and Angelman syndromes. Annu Rev Genomics Hum Genet 2001; 2: 153-175.
[245] DeBaun MR, Niemitz EL, Feinberg AP. Association of in vitro fertilization with Beckwith-Wiedemann syndrome and epigenetic alterations of LIT1 and H19. Am J Hum. Genet.2003; 72: 156-160.

[246] Koshla S, Dean W, Reik W, Feil R. Epigenetic and experimental modifications in early mammalian development: Part II Culture of preimplantation embryos and its long-term effects on gene expression and phenotype. Hum Reprod Update 2001; 7: 419-427.

[247] Skaletsky H, Kuroda-Kawaguchi T, Minx PJ, Cordum HS, Hillier $\mathrm{L}$, Brown LG, et al. The male-specific region of the human $\mathrm{Y}$ chromosome is a mosaic of discrete sequence classes. Nature 2003; 423: 825-837. 